\title{
Gas flow unified measurement system for sequential measurement of gas diffusion and gas permeability of partially hydrated geosynthetic clay liners
}

\author{
Md A. Rouf, Abdelmalek Bouazza, Rao M. Singh, Will P. Gates, and R. Kerry Rowe
}

\begin{abstract}
A gas flow unified measurement system (UMS-G) for sequential measurement of gas diffusion and gas permeability of geosynthetic clay liners (GCLs) under applied stress conditions (2 to $20 \mathrm{kPa}$ ) is described. Measurements made with the UMS-G are compared with measurements made with conventional experimental devices and are found to give similar results. The UMS-G removes the need to rely on two separate systems and increases further the reliability of the gas properties' measurements. This study also shows that the gas diffusion and gas permeability reduce greatly with the increase of both gravimetric water content and apparent degree of saturation. The effect of applied stress on gas diffusion and gas permeability is found to be more pronounced at gravimetric water content greater than $60 \%$. These findings suggest that at a nominal overburden stress of $20 \mathrm{kPa}$, the GCL used in the present investigation needs to be hydrated to $134 \%$ gravimetric water content (65\% apparent degree of saturation) before gas diffusion and gas permeability drop to $5.5 \times 10^{-11} \mathrm{~m}^{2} \cdot \mathrm{s}^{-1}$ and $8.0 \times 10^{-13} \mathrm{~m} \cdot \mathrm{s}^{-1}$, respectively, and to an even higher gravimetric water content (apparent degrees of saturation) at lower stress.
\end{abstract}

Key words: geosynthetic clay liner, gas flow, diffusion, advection, gravimetric water content.

Résumé : Dans le cadre de cette étude, on décrit un système de mesure du flux gazeux unifié (UMS-G) afin de mesurer séquentiellement la diffusion gazeuse et la perméabilité au gaz des membranes géosynthétiques d'étanchéité d'argile (GCL) soumises à des conditions de contrainte ( 2 à $20 \mathrm{kPa}$ ). Les mesures prises au moyen de l'UMS-G sont comparées aux mesures obtenues au moyen de dispositifs expérimentaux courants et il s'avère que les résultats sont semblables. En utilisant l'UMS-G, il n'est plus nécessaire d'avoir deux systèmes séparés et la fiabilité des mesures des propriétés des gaz augmente davantage. De plus cette étude démontre que la diffusion gazeuse et la perméabilité au gaz diminuent considérablement lorsqu’à la fois la teneur en eau gravimétrique et le degré de saturation apparent augmentent. Lorsque la teneur en eau gravimétrique est supérieure à $60 \%$, on constate que l'effet de la contrainte appliquée sur la diffusion gazeuse et la perméabilité au gaz est plus prononcé. Ces résultats suggèrent que sous une surcharge de $20 \mathrm{kPa}$, la GCL utilisée aux fins de cette investigation doit subir une hydratation jusqu'à une teneur en eau gravimétrique de 134 \% (degré de saturation apparent de $65 \%$ ) avant que la diffusion gazeuse et la perméabilité au gaz ne baissent jusqu'à $5.5 \times 10^{-11} \mathrm{~m}^{2} \cdot \mathrm{s}^{-1}$ et à $8.0 \times 10^{-13} \mathrm{~m} \cdot \mathrm{s}^{-1}$, respectivement, et jusqu'à une teneur en eau gravimétrique encore plus élevée (degré de saturation apparent) à des contraintes plus faibles. [Traduit par la Rédaction]

Mots-clés : membrane géosynthétique d'étanchéité d’argile (GCL), flux gazeux, diffusion, advection, teneur en eau gravimétrique.

\section{Introduction}

Evaluation of gas migration is important in engineered cover systems of waste containment facilities to prevent or minimize possible contamination of the environment following their closure due to gas build-up. Movement of gases in porous media occurs by two major transport mechanisms: advective and diffusive flow. Gases such as methane and carbon dioxide, generated as a result of anaerobic decomposition of organic materials in municipal solid waste landfills, tend to move in response to a gradient in total pressure (i.e., advective flow) (Vangpaisal and Bouazza 2004; Rouf et al. 2015a) whereas atmospheric methane oxidation and uptake tend to be controlled by oxygen $\left(\mathrm{O}_{2}\right)$ diffusion (Gebert et al. 2011; Yao et al. 2015). In mining waste storage facilities, the gas transport mechanism is more diffusion dominated. For example, oxidation of reactive sulphide-bearing mine residues leading to acid drainage is caused by diffusive influx of oxygen through the cover (Aubertin et al. 2000; Johnson and Hallberg 2005;
Bouazza and Rahman 2007). In the case of uranium tailings, diffusive efflux of radon gas needs to be controlled to reduce its impact on human health (Ferry et al. 2002; Mudd 2008).

The design of these cover systems is, in most cases, site-specific and depends usually on the prevailing climatic conditions. In areas with humid climates, the conventional approach to cover systems (usually multi-layered systems) is to construct a "resistive barrier" that utilizes a liner with a low saturated hydraulic conductivity (i.e., compacted clay liner or geosynthetic clay liner) or composite liners (i.e., compacted clay liner or geosynthetic clay liner + geomembrane), in combination with a number of other soil layers, to reduce or control water infiltration and gas ingressegress into-from the waste. Geosynthetic clay liners (GCLs) are now used increasingly in landfill covers as the resistive barrier, as an alternative to compacted clay liners (Didier et al. 2000; Bouazza 2002; Kim and Benson 2004; Scalia and Benson 2011; Bouazza et al. 2013; Makusa et al. 2014). Their use has also been included in the

Received 17 March 2015. Accepted 5 January 2016.

M.A. Rouf. Department of Civil Engineering, 18 Alliance Lane, Monash University, VIC 3800, Australia.

A. Bouazza and W.P. Gates. Department of Civil Engineering, 23 College Walk, Monash University, VIC 3800, Australia.

R.M. Singh. Department of Civil and Environmental Engineering, 24 AA 02, University of Surrey, Guildford, GU2 7XH UK.

R.K. Rowe. Department of Civil Engineering, Queen's University, Ellis Hall, Kingston, ON K7L 3N6, Canada.

Corresponding author: Abdelmalek Bouazza (email: malek.bouazza@monash.edu). 
construction of mine cover systems as replacement of soil resistive barriers, at least in humid or wet climates (Aubertin et al. 2000; Kim and Benson 2004; Renken et al. 2005; Bouazza and Rahman 2007; Hosney and Rowe 2013, 2014; Rowe and Hosney 2013).

There is a wide body of work available on GCL hydraulic performance and the measurements of GCL permeability and diffusivity to fluids are well documented in literature (Rowe 1998; Lake and Rowe 2000; Shackelford et al. 2000; Bradshaw and Benson 2013; Abuel-Naga and Bouazza 2014; Bouazza and Gates 2014; Bouazza et al. 2014; Liu et al. 2014, 2015; Rowe et al. 2014; Shackelford 2014), thus it will not be the focus of this paper. However, experimental measurements of GCL permeability and diffusion of gases are less widely available and information on GCL gas advective and diffusive flow performance has become available only in the last decade (Bouazza and Vangpaisal 2004, 2007; Vangpaisal and Bouazza 2004; Bouazza et al. 2006, 2008; Bouazza and Rahman 2007; Abuel-Naga and Bouazza 2009; Mendes et al. 2010; Pitanga et al. 2011; Rouf et al. 2015a). Gas permeability of GCLs has been shown to be affected by changes in gravimetric-volumetric water content (Didier et al. 2000; Bouazza and Vangpaisal 2003; Vangpaisal and Bouazza 2004; Pitanga et al. 2011; Rouf et al. 2013, 2015a), amount of straining (Bouazza and Vangpaisal 2004), distribution of needle-punched fibres in GCLs (Bouazza and Vangpaisal 2007), as well as the form of bentonite (powdered or granular) used in GCLs (Vangpaisal and Bouazza 2004). Additionally, bentonite impregnation of the geotextile component was found to reduce the gas permeability of GCLs considerably (Vangpaisal and Bouazza 2004). It was also reported by previous researchers (Bouazza et al. 2006; Mendes et al. 2010) that when a GCL lost the absorbed water, its gas permeability significantly augmented due to shrinkage of the bentonite component and, in severe cases, due to the formation of desiccation cracks that provided preferential gas flow paths due to pressure gradient. Earlier work has also shown that an increase in degree of saturation greatly attenuated the gas diffusion coefficient of GCLs (Aubertin et al. 2000; Bouazza and Rahman 2004, 2007). Furthermore, Bouazza and Rahman (2007) indicated that the way that GCLs are held together as a composite material (i.e., stitch bonded versus needle punched) had a significant effect on the variation of gas diffusivity.

Traditionally, two separate devices have been used to quantify the gas advective and diffusive properties of GCLs: a gas permeameter to measure the gas permeability (Bouazza and Vangpaisal 2003) and a diffusion cell to measure gas diffusion (Aubertin et al. 2000; Bouazza and Rahman 2007). This process makes it cumbersome to evaluate the gas flow properties of GCLs. Furthermore, such methods are fraught with uncertainties because specimens used in both devices may differ substantially (i.e., different mass per unit area (Ali et al. 2014; Rouf et al. 2015b), thickness (Meer and Benson 2007; Rouf et al. 2015a, 2015b) even if they are from the same roll). This paper presents a gas flow unified measurement system (UMS-G) that allows the measurement of gas diffusion and permeability sequentially on the same specimen, thus removing the need to rely on two separate systems and increasing further reliability of the gas properties measurements.

\section{Mechanism of gas transport}

The movement of gas in porous media such as soils or GCLs is mainly governed by two physical transport mechanisms: diffusion and advection. A brief description of the diffusion and advection processes is given below.

\section{Diffusion}

Diffusion is a physical process where gas movement occurs due to molecular interactions and mass flow (Troeh et al. 1982; Aubertin et al. 2000; Allaire et al. 2008; Barral et al. 2010). When a gas is more concentrated in one region of a mixture than another, gas tends to diffuse into the less concentrated region. Thus the molecules move in response to a partial pressure, or gas concentration gradient. The movement of gas molecules will occur through the air-filled pores in the case of unsaturated porous media while for the highly saturated porous media it will occur partly through the gas phase and partly in the liquid phase, implying in this latter a solubilization process (Aubertin et al. 2000; Bouazza and Rahman 2004, 2007). The primary driving force for gas transport in mine tailings cover is the $\mathrm{O}_{2}$ concentration gradient formed between the atmosphere and mine tailings (Lundgren 2001; Bouazza and Rahman 2007).

Fick's laws can be used to model gas diffusion in a similar way to diffusion transport of dissolved contaminants through porous media (Aubertin et al. 2000; Bouazza and Rahman 2007). The mass diffusive flux for the one-dimensional diffusion process is given by Fick's first law

$$
J=-D_{\mathrm{p}} \frac{\partial C_{\mathrm{g}}}{\partial z}
$$

where $J$ is the mass diffusive flux of the gas $\left(\mathrm{g} \cdot \mathrm{m}^{-2} \cdot \mathrm{s}^{-1}\right), D_{\mathrm{p}}$ is the diffusion coefficient of the gas $\left(\mathrm{m}^{2} \cdot \mathrm{s}^{-1}\right), C_{\mathrm{g}}$ is the concentration difference in the gaseous phase $\left(\mathrm{g} \cdot \mathrm{m}^{-3}\right), z$ is a distance (thickness, height, etc.) $(\mathrm{m})$, and $\partial C_{\mathrm{g}} / \partial z$ is the concentration gradient $\left(\mathrm{g} \cdot \mathrm{m}^{-4}\right)$. The minus sign in eq. (1) indicates that mass transfer over time occurs in the direction of decreasing concentration.

The transient one-dimensional diffusion of a nonreactive gas can be derived from the continuity equation and Fick's first law and is described by Fick's second law as given below:

$$
\varepsilon\left(\frac{\partial C_{g}}{\partial t}\right)=D_{p}\left(\frac{\partial^{2} C_{g}}{\partial z^{2}}\right)
$$

where $\varepsilon$ is the air-filled porosity $\left(\mathrm{m}^{3} \cdot \mathrm{m}^{-3}\right)$, and $t$ is the time $(\mathrm{s})$. Assuming that the sample porous medium is uniform with respect to diffusion coefficient and $\varepsilon$ is constant in space and time, eq. (2) can be solved subject to the boundary and initial conditions for the diffusion chamber method (Currie 1960; Rolston and Moldrup 2002). Hence, eq. (2) can be used for the calculation of the diffusion coefficient, which is dependent on the pores and fluid characteristics, such as total porosity, tortuosity, degree of saturation, and molecular weight.

\section{Advection}

Advection is a process of gas flow in which the gas moves in response to a gradient in total pressure (Troeh et al. 1982; Bouazza and Vangpaisal 2003; Vangpaisal and Bouazza 2004; Barral et al. 2010). A mass of gas travels from a region of higher pressure to a lower pressure until pressure equilibrium is reached. In the context of landfills, the primary driving force for gas migration, especially through cover systems, is a pressure differential due to natural fluctuations in atmospheric pressure (Vangpaisal and Bouazza 2004). Other factors that can also contribute to the pressure differential are changes in the leachate - water table or temperature (Lundgren 2001; Vangpaisal and Bouazza 2004). Other major mechanisms driving gas migration include elevated internal gas pressure resulting from gas generation caused by bacterial decomposition, volatilization and chemical reactions (McBean et al. 1995), and gas density-driven transport (Thomas et al. 2010).

Several past studies have shown that Darcy's law could provide a fair approximation of advective gas flow in a low-permeability material (Alzaydi et al. 1978; Bouazza and Vangpaisal 2003; Vangpaisal and Bouazza 2004). Furthermore, Massmann (1989) indicated that a groundwater flow model provides a good approximation for gas advection up to a differential pressure of $50 \mathrm{kPa}$.

The one-dimensional volumetric flow rate $Q\left(\mathrm{~m}^{3} \cdot \mathrm{s}^{-1}\right)$ of gas in porous media can be described by Darcy's law as shown below: 


$$
\text { (3) } \quad Q=-\frac{k}{\mu} A \frac{d P}{d z}
$$

where $k$ is the intrinsic permeability of the porous material $\left(\mathrm{m}^{2}\right)$, $A$ is the cross-sectional area of the porous material $\left(\mathrm{m}^{2}\right), d \mathrm{P} / d z$ is pressure gradient, and $\mu$ is dynamic viscosity of gas $\left(\mathrm{N} \cdot \mathrm{s} \cdot \mathrm{m}^{-2}\right)$. Generally, intrinsic permeability is considered a property of porous materials, which is independent of permeating gas-fluid.

The gas permeability, $K\left(\mathrm{~m} \cdot \mathrm{s}^{-1}\right)$, of any porous media can be estimated from the equation given below:

$$
K=\frac{\rho g}{\mu} k
$$

where $\rho$ is density of the gas $\left(\mathrm{kg} \cdot \mathrm{m}^{-3}\right)$ and $\mathrm{g}$ is gravitational acceleration $\left(\mathrm{m} \cdot \mathrm{s}^{-2}\right)$.

Applying the continuity equation and assuming that landfill gas behaves as an ideal gas, eq. (3) can be expressed as

$$
P Q d z=-\frac{k}{\mu} A P d P
$$

For a specimen of length $L(\mathrm{~m})$, eq. (5) may be integrated subject to boundary conditions: $P=P_{1}$ at $z=0$ and $P=P_{2}$ at $z=L$, where $P_{2}$ is the atmospheric pressure, to give the mass flow rate entering the atmosphere $\left(Q_{2}\right)$, in terms of boundary pressure, viz:

$$
Q_{2}=\frac{k}{\mu} A \frac{P_{1}^{2}-P_{2}^{2}}{2 P_{2} L}
$$

By combining eqs. (4) and (6), gas permeability can be expressed as

$$
K=\frac{2 Q_{2} P_{2} L \rho g}{A\left(P_{1}^{2}-P_{2}^{2}\right)}
$$

\section{Materials and methods}

\section{Geosynthetic clay liner}

The commercially available GCL examined in the present investigation was composed of powdered sodium bentonite sandwiched between a nonwoven geotextile (NW) cover layer and a woven geotextile $(\mathrm{W})$ carrier layer with the system being needlepunched together and thermally treated to provide confinement of the bentonite during transport and placement. The mass per unit area of bentonite $\left(M_{\text {bent }}\right)$ was calculated from the difference between the mass per unit area of the GCL $\left(M_{\mathrm{GCL}}\right)$ and the mass per unit area of the geotextiles $\left(M_{\mathrm{GT}}\right) \cdot \mathrm{M}_{\mathrm{GCL}}$ and $M_{\mathrm{GT}}$ were obtained following the procedures outlined in ASTM (2014) standard D5993 and ASTM (2010) standard D5261, respectively. The GCL physical characteristics are shown in Table 1.

\section{Specimen preparation}

GCL specimens were prepared and hydrated to cover various conditions (i.e., gravimetric water contents and hydration processes). Firstly, $135 \mathrm{~mm}$ diameter GCL specimens were cut, from an A-3 sized GCL sheet (previously cut from a GCL roll), using a sharp knife and a plastic disc as a cutting base. One specimen from each A-3 sized GCL sheet was used to measure initial thickness, mass, and gravimetric water content. The initial thickness and mass of each GCL specimen was also recorded to facilitate further analysis. The GCL specimens were selected in such a way that the mass per unit area of the GCL specimens fell within the representative range of mass per unit area histogram shown in Fig. 1 . The histogram is not normally distributed due to the lack of uniformity in mass per unit area at different locations of the roll. Thus
Table 1. Characteristics of GCL used in this study.

\begin{tabular}{ll}
\hline Parameter & Type or value \\
\hline $\begin{array}{l}\text { Bentonite } \\
\text { Bonding }\end{array}$ & $\begin{array}{l}\text { Sodium-powdered } \\
\text { Needle punched and } \\
\text { thermally treated } \\
\text { Nonwoven }\end{array}$ \\
$\begin{array}{l}\text { Upper geotextile } \\
\text { Lower geotextile }\end{array}$ & $\begin{array}{l}4.5-5.9 \\
\text { GCL mass per unit area, } M_{\mathrm{GCL}}\left(\mathrm{kg} \cdot \mathrm{m}^{-2}\right)\end{array}$ \\
$\begin{array}{l}\text { Bentonite mass per unit area, } M_{\mathrm{bent}}\left(\mathrm{kg} \cdot \mathrm{m}^{-2}\right) \\
\text { Upper geotextile mass per unit area, }\end{array}$ & $\begin{array}{l}\text { are-5.4 } \\
\quad M_{\mathrm{UG}}\left(\mathrm{kg} \cdot \mathrm{m}^{-2}\right)\end{array}$ \\
$\begin{array}{l}\text { Lower geotextile mass per unit area, } \\
M_{\mathrm{LG}}\left(\mathrm{kg} \cdot \mathrm{m}^{-2}\right)\end{array}$ & 0.30 \\
Thickness of upper geotextile, $H_{\mathrm{UG}}(\mathrm{mm})$ & $2.30-2.68$ \\
Thickness of lower geotextile, $H_{\mathrm{LG}}(\mathrm{mm})$ & $0.49-0.58$ \\
Thickness of as-received GCL, $H_{\mathrm{GCL}}(\mathrm{mm})$ & $6.18-6.86$ \\
\hline
\end{tabular}

there is potential for a substantial variation in the mass per unit area if the specimens are cut without referring to the representative mass per unit area histogram. This in turn can have a significant impact on gas migration as indicated by Bouazza and Rahman (2007).

The specimens were conditioned by placing them on a saturated porous plate to uptake moisture for different specified time periods (bottom-up hydration process). Once the target time was reached the specimens were removed from the moisture uptake set-up and stored in a double re-sealable plastic bag for hydrationmoisture equilibration. The moisture equilibration of the specimen took place gradually until all available water was absorbed by the bentonite as dry bentonite has a very high negative water potential. For this reason, the equilibration of GCL after moisture uptake was essential. The specimens were hydrated-equilibrated following two different methods. In the first method, the GCL was kept under a normal stress of $20 \mathrm{kPa}$ by direct loading, to simulate the weight of a $1 \mathrm{~m}$ thick soil layer typically used in a cover system, at least in humid climates (Hosney and Rowe 2013). However, it is important to point out that Meer and Benson (2007) indicated that $1 \mathrm{~m}$ cover soil might not be sufficient to minimize changes in hydraulic conductivity of GCLs caused by dehydration-desiccation and cation exchange. In the second method, the GCL was placed under $2 \mathrm{kPa}$ vertical confinement to provide a minimum stress to ensure uniform distribution of moisture content in the specimen. An equilibration period of 10-14 days was used to ensure a uniform distribution of moisture in the GCL specimens (see also section titled "Moisture content verification") prior to sequential measurement of gas diffusion and gas permeability.

\section{Apparatus and test procedures}

\section{Gas flow unified measurement system (UMS-G)}

The gas flow unified measurement system (UMS-G) for measuring GCL gas diffusion and permeability (Fig. 2) was developed by integrating and improving a diffusion chamber method (Currie 1960; Rolston and Moldrup 2002), a gas permeability apparatus (Bouazza and Vangpaisal 2003), and a recently developed soil unified measurement system (UMS_SC) for gas transport parameters with suction control (Rouf et al. 2012). The UMS-G comprises three major parts, all made of acrylic: a bottom cylindrical diffusion chamber (100 $\mathrm{mm}$ in inner diameter and $95 \mathrm{~mm}$ in height), a middle cylinder to accommodate a GCL specimen, and a cylindrical top-upper chamber $(100 \mathrm{~mm}$ in inner diameter and $70 \mathrm{~mm}$ in height) with a moveable steel piston. The three parts are held together with four threaded retaining rods. The diffusion chamber was equipped with two measurement ports-valves, an $\mathrm{O}_{2}$ electrode (KE-25, Figaro Engineering Inc., Japan), and a pressure transducer (MBR20, range: $0-1$ bar $(1 \mathrm{bar}=100 \mathrm{kPa})$; precision: 0.25\%; MeasureX Pty Ltd., Melbourne, Australia). The $\mathrm{O}_{2}$ electrode 
Fig. 1. Histogram of GCL mass per unit area.

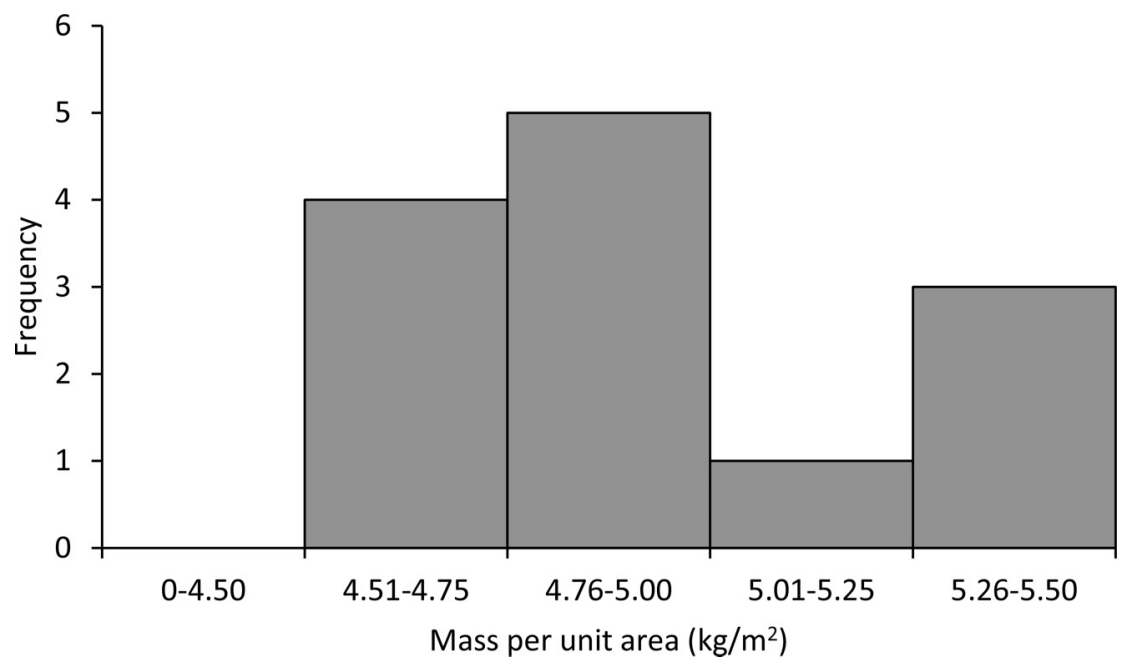

Fig. 2. Schematic design of the experimental setup for the gas flow unified measurement system (UMS-G).

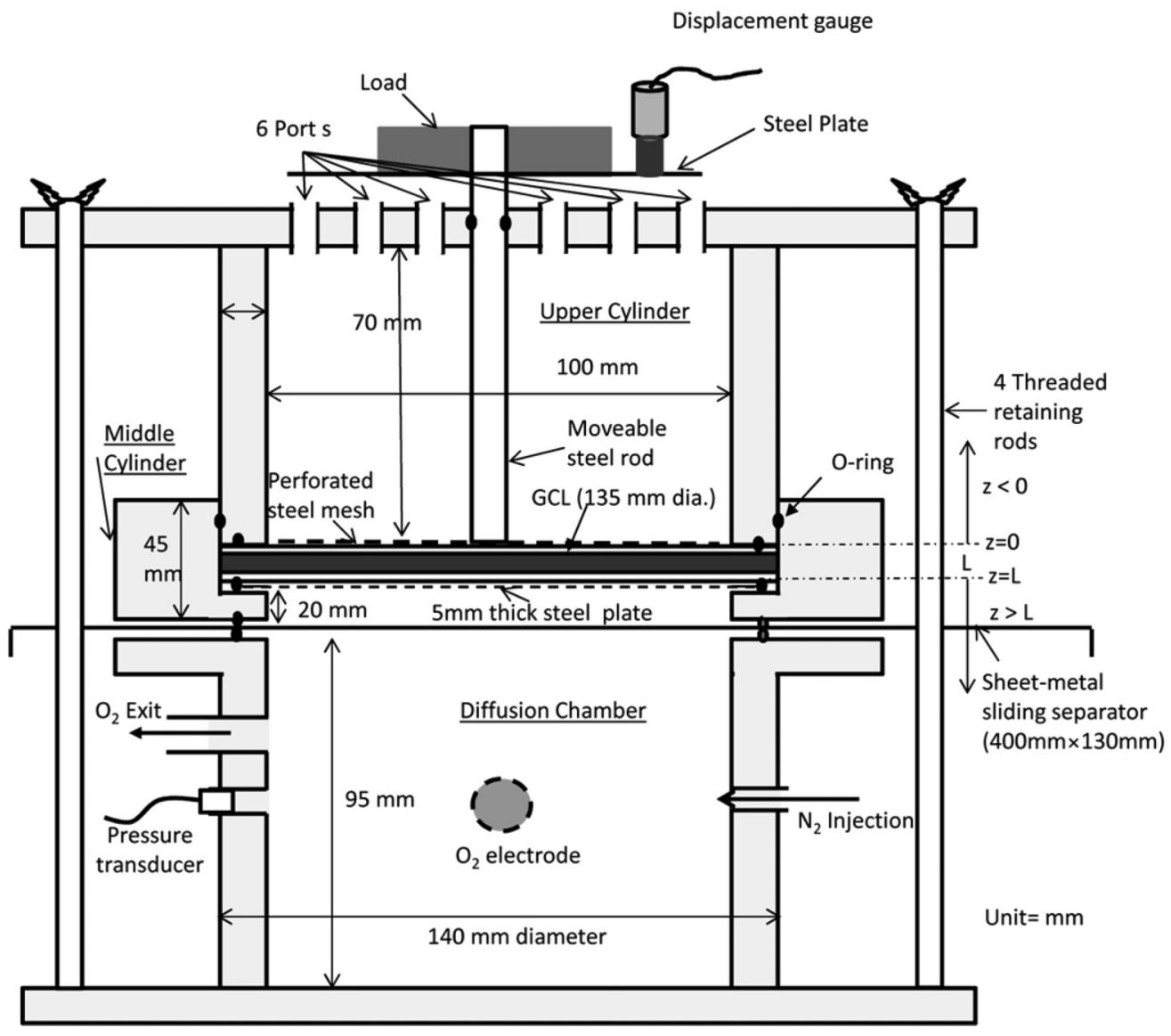

was used to measure the $\mathrm{O}_{2}$ concentration variations inside the diffusion chamber. The function of the pressure transducer was to monitor the pressure variations inside the diffusion chamber. The middle cylinder has two different diameters for the upper and lower part. The upper part has a diameter of $140 \mathrm{~mm}$ and the lower part has a diameter of $100 \mathrm{~mm}$, creating a shoulder on the wall. This shoulder was used to accommodate the GCL specimen and upper cylinder. A groove was made at the top surface of the bottom cylinder and at the bottom surface of the middle cylinder to accommodate a sheet-metal sliding separator $(130 \mathrm{~mm} \times$ $400 \mathrm{~mm}$ ) containing a $100 \mathrm{~mm}$ diameter hole. The purpose of the fitted sheet-metal sliding separator between the diffusion chamber and the middle cylinder is to control the movement of gas by opening or closing the hole. As the hole diameter in the sheetmetal sliding separator was $100 \mathrm{~mm}$, the effective gas flow area of the UMS-G was $7.85 \times 10^{-3} \mathrm{~m}^{2}$. O-rings were provided both in the grooves of the middle cylinder and the bottom cylinder for sealing as well as to ensure a smooth movement of the sheet-metal sliding separator. The upper cylinder consisted of six ports (10 mm diameter; connected to atmosphere) located on the top cap with stoppers and a moveable steel rod (piston) inserted through its centre. The six ports can be unstoppered during the subsequent gas diffu- 
sion measurements. During gas permeability measurement only one port was kept open. A set of five interchangeable gas flowmeters (GFM17 Mass Flow Meters, Aalborg, Denmark; accuracy: 1.5\% of full range at $20^{\circ} \mathrm{C}$ and atmospheric pressure) was attached to this port to record gas outflow ranging from $0-10 \mathrm{~cm}^{3} \cdot \mathrm{min}^{-1}$ to $0-15000 \mathrm{~cm}^{3} \cdot \mathrm{min}^{-1}$. The purpose of the moveable steel rod situated in the upper cylinder was to transmit the target applied stress to the GCL specimen through the perforated steel mesh $(100 \mathrm{~mm}$ diameter) attached at the bottom of the rod. A steel plate was also attached to the top portion of the moveable steel rod to allow load application during the test. In addition, a displacement gauge (LP-20F, Midori Precisions, ADM Instruments Engineering, Australia) was installed on top of the steel plate to record the change in thickness of the GCL specimen during the test. The connections of the upper cylinder with the middle cylinder wall and with the moveable steel rod were sealed using O-rings. A $5 \mathrm{~mm}$ thick and $140 \mathrm{~mm}$ diameter (but $100 \mathrm{~mm}$ inner diameter perforated) steel plate was placed on the shoulder of the middle cylinder to avoid a possible sagging of the GCL due to the applied load as there was no subgrade material below the GCL in the set-up system. O-rings were provided both at the shoulder of the middle cylinder and above the perforated steel plate to avoid gas leakage in lateral direction through the interface. The $\mathrm{O}_{2}$ electrodes, pressure transducer, and displacement gauge were connected to a data logger (DT 505, Data Taker Pty Ltd., Melbourne, Australia) and a computer for monitoring and storage of the data. Nitrogen $\left(\mathrm{N}_{2}\right)$ gas $\left(\mu=1.76 \times 10^{-5} \mathrm{~N} \cdot \mathrm{s} \cdot \mathrm{m}^{-2}, \rho=1.165 \mathrm{~kg} \cdot \mathrm{m}^{-3}\right.$ at $20^{\circ} \mathrm{C}$ at atmospheric pressure) was used as permeating fluid in this investigation because it is relatively inert and has very low water solubility.

\section{Testing procedure}

\section{Specimen assembly process}

The GCL specimen assembly process involved several steps. First, a sheet-metal sliding separator with a $100 \mathrm{~mm}$ diameter hole was fitted with the groove present in the top surface of the diffusion chamber. Next, the middle cylinder was placed above the sheet-metal sliding separator so that its groove fitted well with the sliding separator and groove of the bottom cylinder. Then, a $135 \mathrm{~mm}$ diameter hydrated GCL specimen was placed on the $5 \mathrm{~mm}$ thick ( $>40 \%$ area) perforated steel plate above the shoulder of the middle cylinder. As more than $40 \%$ area of the $5 \mathrm{~mm}$ thick steel plate was perforated, it was assumed that the resistance from the steel plate for gas flow was negligible. Additionally, the gas flow loss test check showed that the perforated steel plate had no resistance to gas flow. Tests were also conducted with and without a steel mesh and no noticeable difference in $\mathrm{O}_{2}$ concentration was observed that could change the gas diffusion coefficient. After completing the GCL specimen placement, four retaining rods were tied to fit and secure the upper cylinder to the middle cylinder and diffusion chamber. Care was taken not to overtighten the retaining rods to avoid squeezing of bentonite from the perimeter under excessive compression. Then, the moveable steel rod was placed above the GCL specimen to allow the application of the target vertical stress ( 2 or $20 \mathrm{kPa}$ ) before the start of the test.

\section{Measurement and calculation of gas diffusion coefficient}

The diffusion test consisted of introducing $\mathrm{N}_{2}$ gas into the diffusion chamber (receptor) to displace the $\mathrm{O}_{2}$ present in the chamber. Both ports-valves of the diffusion chamber were shut off. The $100 \mathrm{~mm}$ diameter hole of the sheet-metal sliding separator was kept open and the six stoppers at the top cap of the upper cylinder $\left(\mathrm{O}_{2}\right.$ source chamber) were opened. This allowed air to diffuse through the specimen to the diffusion chamber thereby increasing the $\mathrm{O}_{2}$ concentration in the diffusion (receptor) chamber. After opening the sheet-metal sliding separator, sufficient time ( $5 \mathrm{~min}$ ) was given to mix the gas inside the diffusion chamber and gas in the space between GCL specimen and the sheet-metal slid- ing separator. Then the $\mathrm{O}_{2}$ concentration in the diffusion chamber was recorded by the $\mathrm{O}_{2}$ electrode at $1 \mathrm{~min}$ intervals.

The calculation of the diffusion coefficient of GCL was conducted according to Fick's second law (eq. (2)). The solution (Carslaw and Jaeger 1959) for the relative concentration $\left(C_{\mathrm{r}}\right)$ in the chamber can be given as

$$
C_{\mathrm{r}}=\frac{C(L, t)-C_{0}}{C_{\mathrm{i}}-C_{0}}=\sum_{n=1}^{\infty} \frac{2 h \exp \left(-D_{\mathrm{p}} \alpha_{n}^{2} t / \varepsilon\right)}{L\left(\alpha_{n}^{2}+h^{2}\right)+h}
$$

Equation (8) can be expressed in a linear form by considering the terms for $n \geq 2$ are negligible with respect to the first term, as shown below:

$$
\begin{aligned}
& \operatorname{Ln}\left(C_{\mathrm{r}}\right)=\operatorname{Ln}\left(\frac{C(L, t)-C_{0}}{C_{i}-C_{0}}\right) \\
&=-\frac{D_{\mathrm{p}} \alpha_{1}^{2}}{\varepsilon} t+\operatorname{Ln}\left[\frac{2 h}{L\left(\alpha_{1}^{2}+h^{2}\right)+h}\right]
\end{aligned}
$$

where $L$ is the height or thickness of sample $(\mathrm{m}), C(\mathrm{~L}, t)$ is the gas concentration in the diffusion chamber at time $t>0\left(\mathrm{~g} \cdot \mathrm{m}^{-3}\right)$, at $z>L ; C_{0}$ is the gas concentration in the atmosphere (source) $\left(\mathrm{g} \cdot \mathrm{m}^{-3}\right)$, at $z<0 ; C_{\mathrm{i}}$ is the gas concentration in the diffusion chamber at $t=0\left(\mathrm{~g} \cdot \mathrm{m}^{-3}\right)$, at $z>\mathrm{L} ; h=\varepsilon / \mathrm{L}_{\mathrm{a}}\left(\mathrm{m}^{-1}\right)$, where $L_{\mathrm{a}}$ is the height of the diffusion chamber + length of the free space below the GCL specimen $(\mathrm{m})$.

Using eq. (9), the GCL gas diffusion coefficient, $D_{\mathrm{p}}$, can be derived from the slope $\left(-D_{\mathrm{p}} \alpha_{1}^{2} / \varepsilon\right)$ of the plot $\operatorname{Ln}\left(C_{\mathrm{r}}\right)$ versus time, $t$, which becomes linear for sufficiently large time as shown in Figs. $3 a$ and $3 b$ at high and low gravimetric water content and stress, respectively. Here, $\alpha_{1}$ is the first positive root of $h L=$ $\alpha_{n} L_{n} \tan \left(\alpha_{n} L_{n}\right)(n=1,2 \ldots)$. From the slope $\left(-D_{\mathrm{p}} \alpha_{1}^{2} / \varepsilon\right)$ of $\operatorname{Ln}\left(C_{\mathrm{r}}\right)$ versus time plot the gas diffusion coefficient can be calculated from estimated values of $\varepsilon$ and $\alpha_{1}$ for each gas diffusion test. In the case of the specimen having a high gravimetric water content, a long testing time was required to measure gas diffusion coefficient accurately. However, the short-time data can be used to estimate the gas diffusion coefficient by considering several terms (up to six terms were used in this investigation) of eq. (8) when $n>1$ as documented by Rolston and Moldrup (2002). For several terms of eq. (8), several positive roots of $\alpha$ can be calculated as explained above (in case of first positive root) from the known value of $\alpha_{n} L_{n}$ given by Carslaw and Jaeger (1959). Up to six roots of $\alpha$ were used in this study to calculate the gas diffusion coefficient at high gravimetric water contents ( $w>70 \%)$.

The boundary conditions for the UMS-G were similar to those for the conventional diffusion chamber method described by Currie (1960) and Rolston and Moldrup (2002). The bottom of the diffusion chamber (Fig. 2) can be assumed to be the zero-gas flux condition and the gas diffusion between the atmosphere and the diffusion chamber occurs through the upper cylinder and six valves (10 $\mathrm{mm}$ in diameter) of the upper cylinder wall.

\section{Measurement and calculation of gas permeability}

To measure gas permeability $(K)$, pressurized $\mathrm{N}_{2}$ gas from a gas cylinder was injected into the diffusion chamber through a port. The differential pressure range of $0-10 \mathrm{kPa}$ was used, as the build-up of gas pressure under a landfill cover system is unlikely to be higher than $10 \mathrm{kPa}$ (McBean et al. 1995). The injected gas passed through the GCL specimen and flowed out through only one outflow port, where a flow meter was attached. The inlet pressure was observed by a pressure transducer installed in the diffusion chamber and the gas outflow was monitored by one of the five flow meters used to cover a range of gas flow rates. The 
Fig. 3. Variation of logarithm of relative oxygen concentration versus elapsed time for $(a)$ two different gravimetric water contents $(8 \%$ and $61 \%)$ and $(b)$ two different ( 2 and $20 \mathrm{kPa}$ ) stress conditions.

(a)

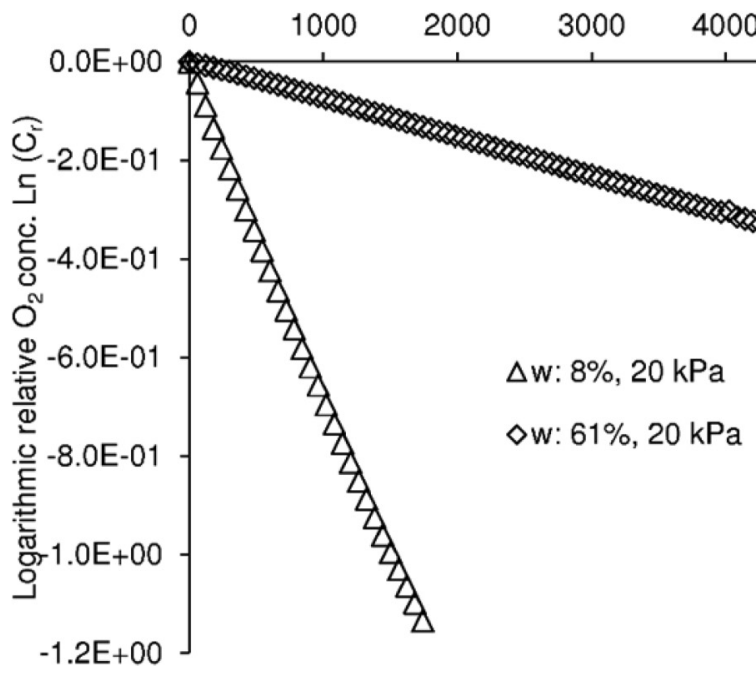

extended Darcy's law (eq. (7)) was used to calculate the gas permeability of the GCL specimen.

Moisture content verification

After completing the sequential measurement of gas diffusion and permeability, the specimen was removed from the UMS-G for visual inspection of possible leakage spots (if any) (i.e., identification of dry spots), Final thickness, weight, and gravimetric water content of the GCL specimen were also recorded for post-test analysis. Furthermore, uniformity of the gravimetric water content across the GCL specimens was verified on selected sacrificial specimens by measuring gravimetric water content from at least four different locations and the average gravimetric water content was reported. The gravimetric water contents of all specimens (on at least four locations for each specimen) were measured on completion of the gas diffusion and permeability tests. A maximum variation of gravimetric water content of $\pm 5 \%$ (from the average value) was deemed acceptable. Specimens having greater gravimetric water content variation were rejected from further analyses. A similar technique was used by Bouazza and Vangpaisal (2003) to verify moisture distribution of their GCL specimens. It is also worth mentioning that GCL moisture losses were insignificant $(<1 \%)$ during the tests; this was confirmed by conducting mass measurement of the GCL specimens before and after the tests. All the measurements were performed in a temperature-controlled laboratory $\left(20 \pm 1{ }^{\circ} \mathrm{C}\right)$ where density and viscosity of gas are considered to be constant.

\section{Change in thickness}

The displacement gauge installed above the top plate of the moveable steel rod (piston) measured the variation of GCL thickness during the sequential measurement of gas diffusion and permeability. The variation of GCL thickness with time under 2 and $20 \mathrm{kPa}$ stress conditions is shown in Fig. 4. It can be observed that the change in thickness under both stress conditions is negligible. This is probably due to the fact that the GCL specimens have previously been conditioned at the same stress levels during the hydration process. The specimen subjected to a low stress $(2 \mathrm{kPa})$ was thicker than the specimen subjected to a higher stress $(20 \mathrm{kPa})$ due to the ability of the GCL specimen to swell more under a low stress. (b)

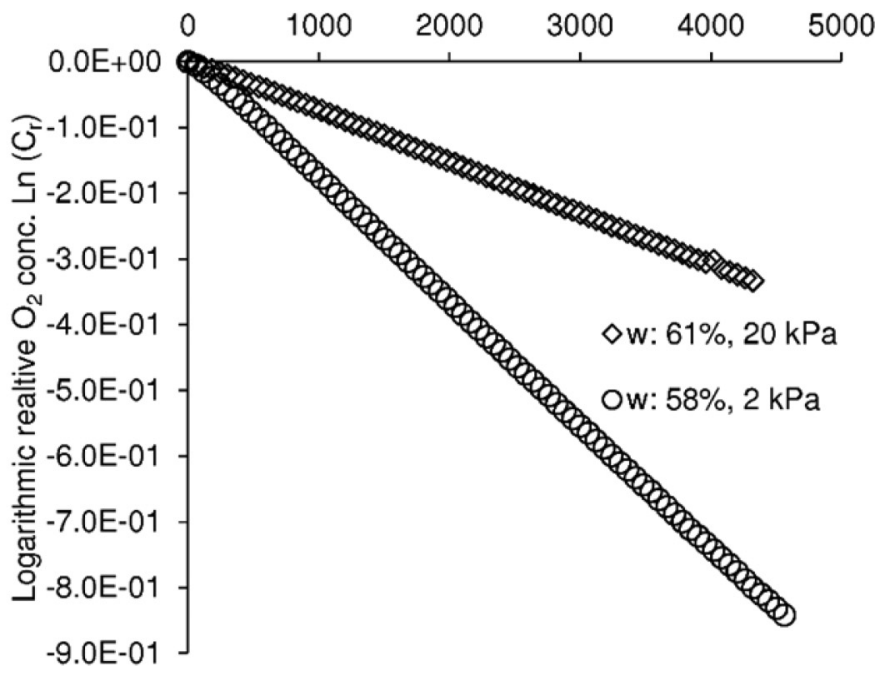

Fig. 4. GCL thickness against time.

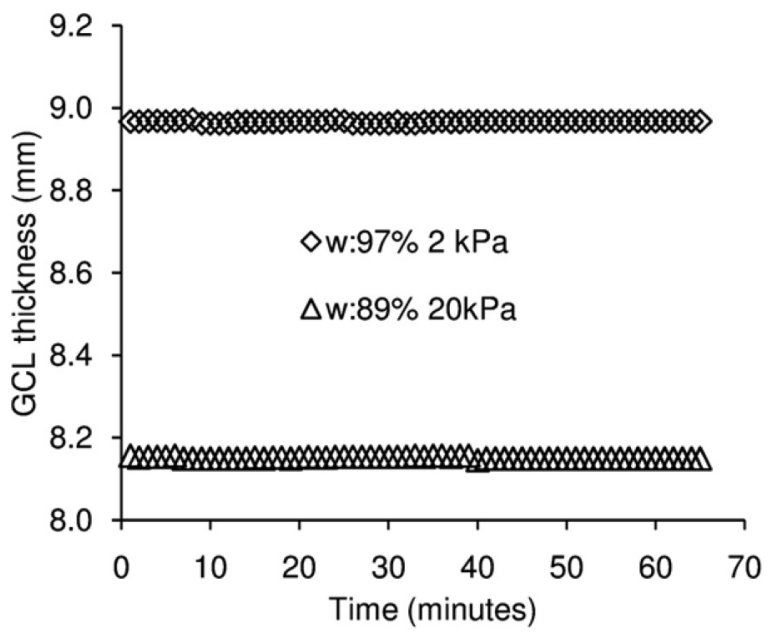

UMS-G leakage and inflow-outflow check

Before starting the experiment, possible gas leakage from the diffusion chamber was checked by injecting $\mathrm{N}_{2}$ gas to bring the $\mathrm{O}_{2}$ concentration of the chamber to near zero. The increase of $\mathrm{O}_{2}$ concentration in the closed diffusion chamber filled with $100 \%$ of $\mathrm{N}_{2}$ gas was found to be less than $0.005 \%$ over a $24 \mathrm{~h}$ period and thus was deemed to be leak-free. The whole system was checked following the same process and less than $0.008 \% \mathrm{O}_{2}$ concentration increase was observed over $24 \mathrm{~h}$, which indicates that top and middle cylinders were also leak-free.

The gas inflow and outflow test of the empty UMS-G is essential to confirm that it will give reliable gas diffusion and permeability results without any flow losses. The $\mathrm{N}_{2}$ gas was injected in the diffusion chamber over a differential pressure ranging from 1 to $10 \mathrm{kPa}$ and measured outflow at the UMS-G outflow port was found to be practically the same (with negligible loss $<0.1 \%$ ), which indicates that almost no resistance to gas flow occurred in the equipment.

\section{Results and discussion}

\section{Gas diffusion coefficient}

The variation of $\mathrm{O}_{2}$ concentration against elapsed time is shown in Figs. $5 a$ and $5 b$ for two different gravimetric water contents $(8 \%$ 
Fig. 5. Oxygen concentration versus elapsed time as percentage of air saturation for (a) two different gravimetric water contents (8\% and $61 \%)$ and $(b)$ two different $(2$ and $20 \mathrm{kPa}$ ) stress conditions.

(a)

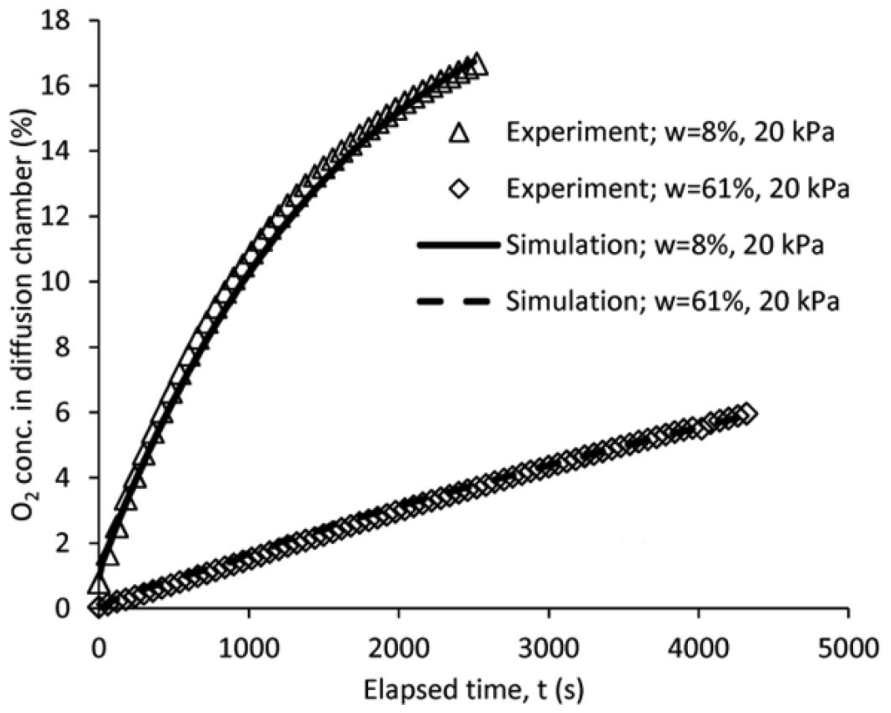

and 61\%) and two different stress conditions ( 2 and $20 \mathrm{kPa}$ ), respectively. Figure $5 a$ shows that $\mathrm{O}_{2}$ concentration increased with time increase due to the flow of atmospheric $\mathrm{O}_{2}$ from the upper cylinder to the diffusion chamber through the GCL specimen. It was also observed that $\mathrm{O}_{2}$ concentration increased by more than $12 \%$ with the reduction of gravimetric water content from $61 \%\left(D_{\mathrm{p}}=\right.$ $\left.7.0 \times 10^{-8} \mathrm{~m}^{2} \cdot \mathrm{s}^{-1}\right)$ to $8 \%\left(D_{\mathrm{p}}=5.5 \times 10^{-7} \mathrm{~m}^{2} \cdot \mathrm{s}^{-1}\right)$ under the same stress $(20 \mathrm{kPa})$ condition. This increase of $\mathrm{O}_{2}$ concentration at low gravimetric water content compared with higher gravimetric water content might be due to the fact that specimens at higher gravimetric water content (61\%) have more interconnected pore spaces filled with water, which allowed less $\mathrm{O}_{2}$ to diffuse through the GCL. Figure $5 b$ shows that $\mathrm{O}_{2}$ concentration increased with time under both 2 and $20 \mathrm{kPa}$ stresses for similar gravimetric water content $(\sim 60 \%)$. The increase in $\mathrm{O}_{2}$ concentration for the specimen under $2 \mathrm{kPa}\left(D_{\mathrm{p}}=1.7 \times 10^{-7} \mathrm{~m}^{2} \cdot \mathrm{s}^{-1}\right)$ was higher than for that under $20 \mathrm{kPa}\left(D_{\mathrm{p}}=7.0 \times 10^{-8} \mathrm{~m}^{2} \cdot \mathrm{s}^{-1}\right)$ due to the reduction of pore spaces and disruption of the pore network at higher stress compared to lower stress.

Numerical simulations were also performed to validate calculation schemes for determining the gas diffusion coefficient using the UMS-G. Transient diffusive $\mathrm{O}_{2}$ gas transport was simulated based on the boundary conditions given for the UMS-G. The governing equation for diffusive gas transport (eq. (2)) was solved numerically by a finite element method using COMSOL Multiphysics version 4.3. The domain was divided into fine meshes with a total of 968 triangular elements (62 elements for the GCL and 906 elements for the diffusion chamber). In addition, the Millington and Quirk (1961) tortuosity model was used to solve $\mathrm{O}_{2}$ concentration numerically with time. $\mathrm{O}_{2}$ concentration within the diffusion chamber at $t=0$ and the atmospheric $\mathrm{O}_{2}$ concentration were used as the initial conditions for the diffusion chamber and the GCL specimen, respectively. The gas diffusion coefficient in air $\left(1.8 \times 10^{-5} \mathrm{~m}^{2} \cdot \mathrm{s}^{-1}\right.$ for $\mathrm{O}_{2}$ at $\left.20^{\circ} \mathrm{C}\right)$ was used as the gas diffusion coefficient in the diffusion chamber and the gas diffusion coefficient calculated using eqs. (8) or (9) was used as gas diffusion coefficient in the GCL specimen. The simulation was done with the same air-filled porosity and thickness of the GCL specimen used in the experiments. The air-filled (effective) porosity was calculated based on the concept proposed by Petrov and Rowe (1997) and Rouf et al. (2015a), which takes into account GCL thickness, mass per unit area of GCL and geotextiles, specific gravity of (b)

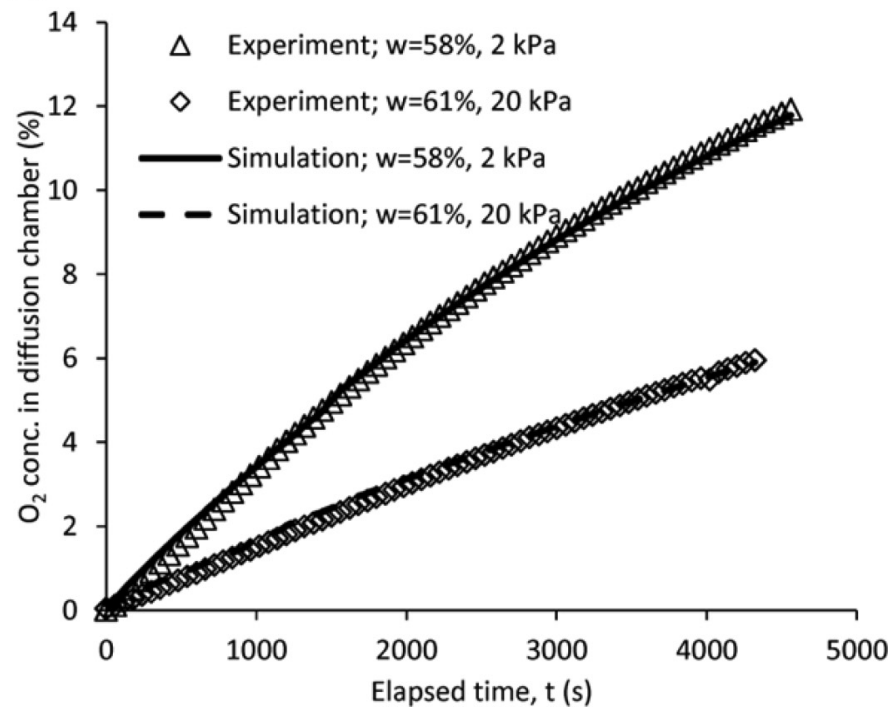

Fig. 6. Variation of gas diffusion coefficient against gravimetric water content under 2 and $20 \mathrm{kPa}$ stress condition.

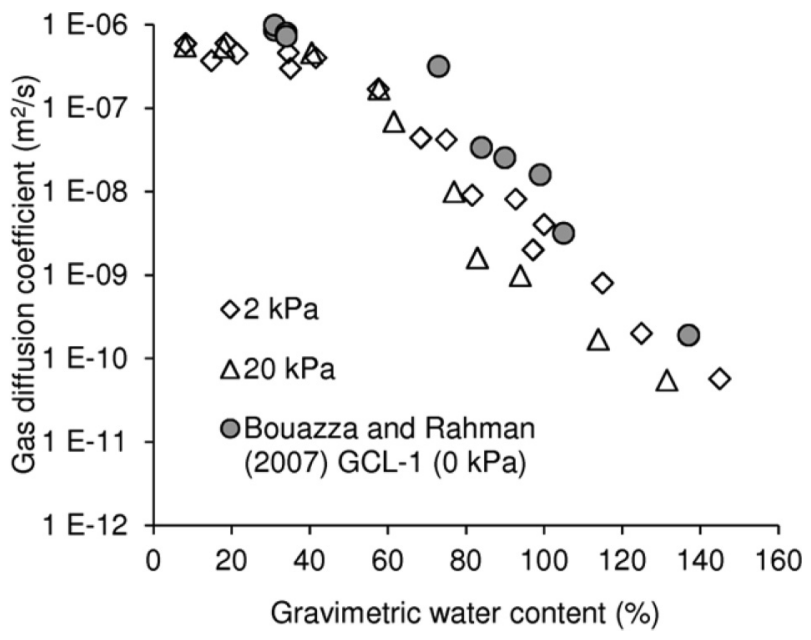

bentonite and geotextiles, and initial water content of the GCL. The simulated $\mathrm{O}_{2}$ concentration was found to be in good agreement with the experimental $\mathrm{O}_{2}$ concentration as shown in Figs. $5 a$ and $5 b$. Therefore, calculation of the gas diffusion coefficient using eqs. (9) or (10) was deemed to be valid.

The calculated (using eqs. (8) and (9)) GCL gas diffusion coefficient $\left(D_{\mathrm{p}}\right)$ was plotted against GCL gravimetric water content in Fig. 6 for 2 and $20 \mathrm{kPa}$ applied stress. $D_{\mathrm{p}}$ decreased with an increase in gravimetric water content under both stresses. At $2 \mathrm{kPa}$ stress, the $D_{\mathrm{p}}$ values decreased by four orders of magnitude when the gravimetric water content increased by about $140 \%$. At $20 \mathrm{kPa}$ stress, about $130 \%$ increase in gravimetric water content caused about four orders of magnitude reduction in the gas diffusion coefficient. Up to $40 \%$ gravimetric water content, no marked difference in gas diffusion coefficient was observed for the conditions considered in this study. This is likely due to the fact that in this range (i.e., $8 \%$ to $40 \%$ gravimetric water content) there was insufficient moisture to reduce-block the air-filled pore network of the specimen and hence to reduce gas diffusion. However, at higher gravimetric water contents $(>40 \%)$ a notable reduction in 
Fig. 7. Reference gravimetric water content for (a) this study GCL at 2 and $20 \mathrm{kPa}$ stress; (b) Bouazza and Rahman (2007) investigation (collected from Vangpaisal (2002)) at $0 \mathrm{kPa}$ stress.

(a)

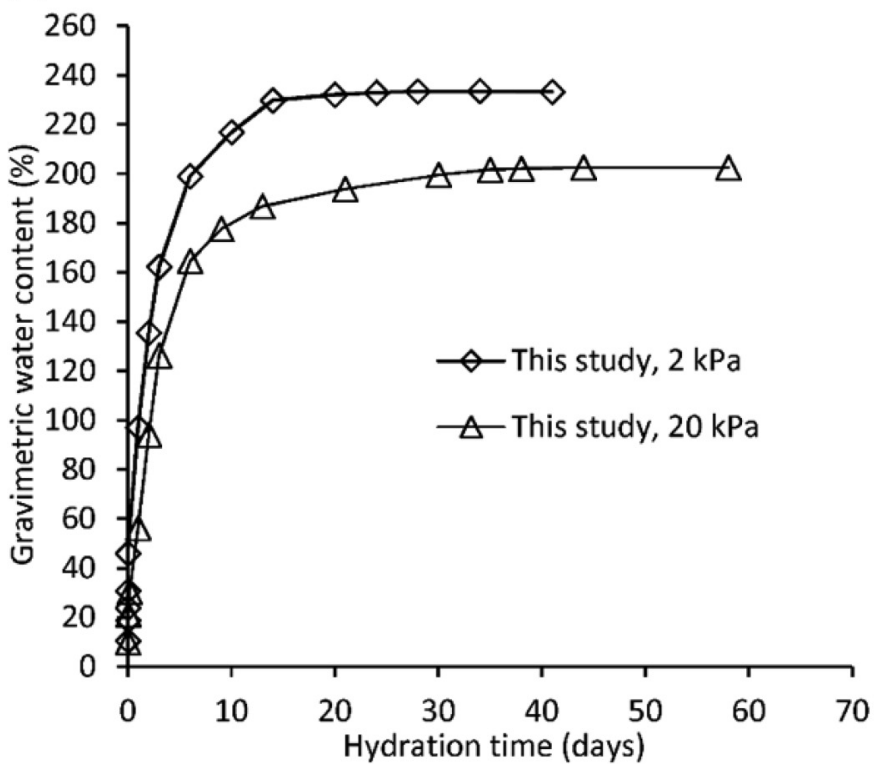

gas diffusion values was observed. Up to $60 \%$ gravimetric water content, the difference in gas diffusion values under 2 and $20 \mathrm{kPa}$ applied stress was small, indicating negligible effect of stress in this range. Norrish (1954) indicated that at gravimetric water content $<60 \%$, the swelling of bentonite is negligible. Due to insignificant bentonite swelling behaviour, the change in pore structure of the GCL specimens investigated under 2 and $20 \mathrm{kPa}$ stresses is negligible; as a result, gas diffusion was not affected by stress. Beyond this range, reduction in the gas diffusion coefficient with gravimetric moisture content was greater under $20 \mathrm{kPa}$ than $2 \mathrm{kPa}$ stress. This reduction is considered to be due to a much greater reduction of pore space and disruption of the air-filled pore networks caused by the higher $20 \mathrm{kPa}$ stress compared to a lower $2 \mathrm{kPa}$ stress condition. Thus, for this GCL, the effect of stress is insignificant up to $60 \%$ gravimetric water content (i.e., for a low degree of saturation as discussed below), but beyond this range the gas diffusion coefficient was only slightly affected by the increase in vertical stress.

Bouazza and Rahman' (2007) gas diffusion coefficient data for GCL-1 under a free swell condition $(0 \mathrm{kPa})$ were also included in Fig. 6 for comparative purposes. GCL-1 is similar to the GCL used in the present investigation, but had a much lower bentonite mass unit area (3.1 to $3.8 \mathrm{~kg} \cdot \mathrm{m}^{-2}$ ) compared to the current GCL (4.0$5.4 \mathrm{~kg} \cdot \mathrm{m}^{-2}$ ). Variation of the diffusion coefficient versus gravimetric water content is similar for both GCLs. However, GCL-1 has slightly higher diffusion coefficient due to its lower bentonite mass unit area. From Fig. 6 it can also be observed that the gas diffusion coefficient variation between 2 and $20 \mathrm{kPa}$ stress conditions is less than $12 \%$ at high GCL gravimetric water content $(>60 \%)$ conditions and negligible below it. Thus, one can deem that the variation of gas diffusion coefficient under 2 and $0 \mathrm{kPa}$ vertical stresses for similar material would be negligible.

Calculation of volumetric water content or degree of saturation for GCL is a challenging task because of the composite nature of GCLs. Previously, an approach was developed by Petrov and Rowe (1997) to calculate bulk void ratio of GCLs. Lake and Rowe (2000) extended that approach to estimate the total porosity of bentonite. They took into account measurement of the GCL thickness, mass per unit area of GCL and geotextiles, specific gravity of bentonite and geotextiles, and initial gravimetric water content of the GCL. However, the thickness of GCLs is difficult to measure accu- (b)

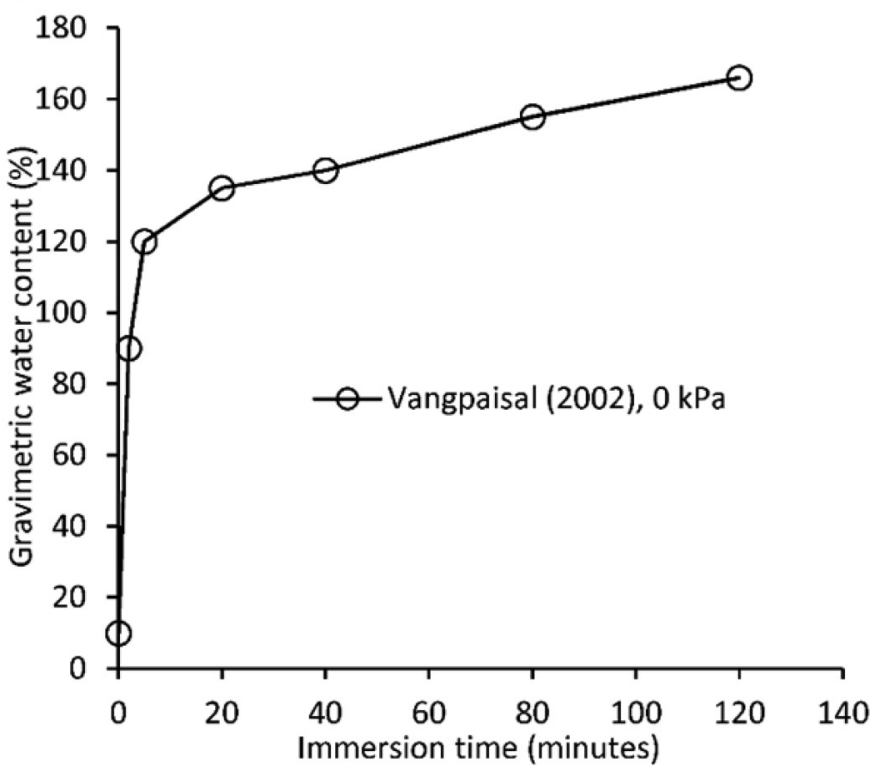

rately due to the presence of geotextiles overlapping the bentonite. Didier et al. (2000) also made an attempt to calculate the porosity of a GCL based on the assumption that all the pores within the geotextile were filled by bentonite, which may not be the actual case for GCLs under unsaturated conditions, even though the bentonite component of GCL can swell and partially fill the geotextile voids during hydration (Bannour et al. 2014). Presence of bentonite in geotextiles can also impact the calculation of bulk void ratio and porosity of GCL. Therefore, calculation of the volumetric water content or actual degree of saturation for a GCL material is a subject for discussion. Due to the abovementioned difficulties Rayhani et al. (2011), Anderson et al. (2012), Rouf et al. (2013), Singh and Bouazza (2013), and Rouf et al. (2015a) used another approach to measure the degree of saturation of GCL specimens having similar mass per unit area based on the concept of apparent degree of saturation instead of the GCL degree of saturation. The apparent degree of saturation can give fairly good indication of GCL pore property variation for different water contents. A limitation of this method is that if the mass per unit area of GCL varies substantially, the resulting variation of apparent degree of saturation may become unreliable. The apparent degree of saturation $\left(S_{\mathrm{r}}^{*}=w / w_{\mathrm{ref}}\right)$ is defined as the gravimetric water content $(w)$ of a GCL at a given time divided by the maximum gravimetric water content $\left(w_{\text {ref }}\right)$ that the same GCL reaches during hydration under the same applied stress conditions. The $w_{\text {ref }}$ values for the GCL under 2 and $20 \mathrm{kPa}$ stressed specimens were $234 \%$ and $203 \%$, respectively (Fig. $7 a$ ); whereas the $w_{\text {ref }}$ value of Bouazza and Rahman's (2007) GCL-1 was 166\% (from Vangpaisal 2002; Fig. $7 b$ ), which was not in true equilibrium indicating that the actual $w_{\text {ref }}$ can be higher than what was reported. Figure 8 shows the variation in the GCL gas diffusion coefficient $\left(D_{\mathrm{p}}\right)$ against the apparent degree of saturation for 2 and $20 \mathrm{kPa}$ applied stresses, as well as Bouazza and Rahman's (2007) GCL-1 gas diffusion coefficient data under zero stress.

Figure 8 shows that $D_{\mathrm{p}}$ of the GCL used in the present study generally decreases with the increase of pparent degree of saturation under 2 and $20 \mathrm{kPa}$ stresses. The gas diffusion coefficient did not decrease in the range up to $20 \%$ apparent degree of saturation (i.e., relatively dry conditions). Above this range, $D_{\mathrm{p}}$ reduced by four orders of magnitude when the apparent degree of saturation 
Fig. 8. Gas diffusion coefficient with respect to GCL apparent degree of saturation.

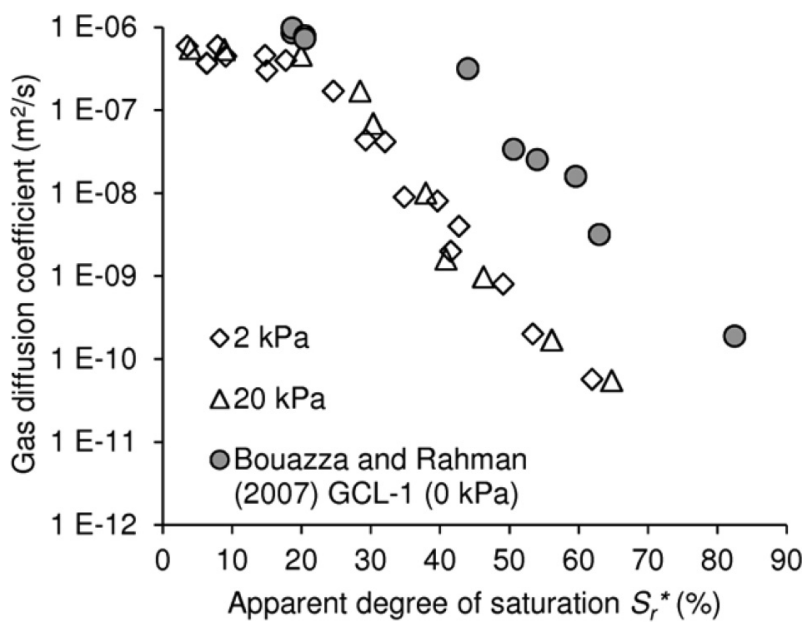

increased from $20 \%$ to $62 \%$ and $20 \%$ to $65 \%$, respectively, for 2 and $20 \mathrm{kPa}$ stress conditions. However, at a given apparent degree of saturation there was very little difference in the values of the diffusion coefficient under the two applied stresses (although the water content required for a given apparent degree of saturation is lower for the $20 \mathrm{kPa}$ stress than the $2 \mathrm{kPa}$ stress). Thus it appears that the apparent degree of saturation tends to affect the diffusion coefficient in this range of stresses as it is a function of the reference water content $\left(w_{\text {ref }}\right)$ at the given target vertical stress as shown above. Bouazza and Rahman's (2007) GCL-1 gas diffusion coefficients under free swell conditions were higher compared to the current data at $2 \mathrm{kPa}$ stress. There are a number of possible explanations for this difference. The presence of lower mass per unit area of bentonite in Bouazza and Rahman's (2007) GCL-1 can increase the gas diffusion due to the presence of higher interconnected pores in bentonite compared to the present study, but such large deviation cannot be explained by material difference only. The observed difference in gas diffusion is most likely due to the use of a reference gravimetric water content $\left(w_{\text {ref }}\right)$ in Bouazza and Rahman's (2007) investigation, which was not based on true equilibrium gravimetric water content as shown in Fig. $7 \mathrm{~b}$. Consequently, the apparent degree of saturation for Bouazza and Rahman's (2007) GCL-1 is much higher. Not surprisingly, Bouazza and Rahman's (2007) GCL-1 under free swell conditions showed higher gas diffusion compared to the present study at $2 \mathrm{kPa}$ vertical stress. It can be inferred from this discussion that the variation of gas diffusion can be comparable if the equilibrium reference gravimetric water content for Bouazza and Rahman's (2007) GCL-1 can be quantified. More importantly, the present work indicates that the newly developed gas measurement device (UMS-G) is capable of measuring gas diffusion reliably.

The GCL gas diffusion coefficient was also plotted against the bentonite degree of saturation $\left(S_{\mathrm{r}}\right)$ as shown in Fig. 9, which included the Bouazza and Rahman (2007) gas diffusion data. Vangpaisal (2002) has shown that at a moisture content $\leq 100 \%$, the degree of saturation of the bentonite component tended to be higher than that of the GCL as a composite material. At a higher moisture content (i.e., $\geq 140 \%$ ) the difference in the degree of saturation of the two materials tended to be lower and in some cases higher $S_{\mathrm{r}}$ values recorded for GCLs were higher than for bentonite due to more water being present in the geotextile components.

Figure 9 shows that $D_{\mathrm{p}}$ decreased by four orders of magnitude when the bentonite degree of saturation increased up to about $\mathbf{9 8 \%}$ for both stress conditions considered in this investigation. Very little difference in gas diffusion coefficient values was observed between the two stress conditions. Furthermore, the
Fig. 9. Gas diffusion coefficient versus bentonite degree of saturation.

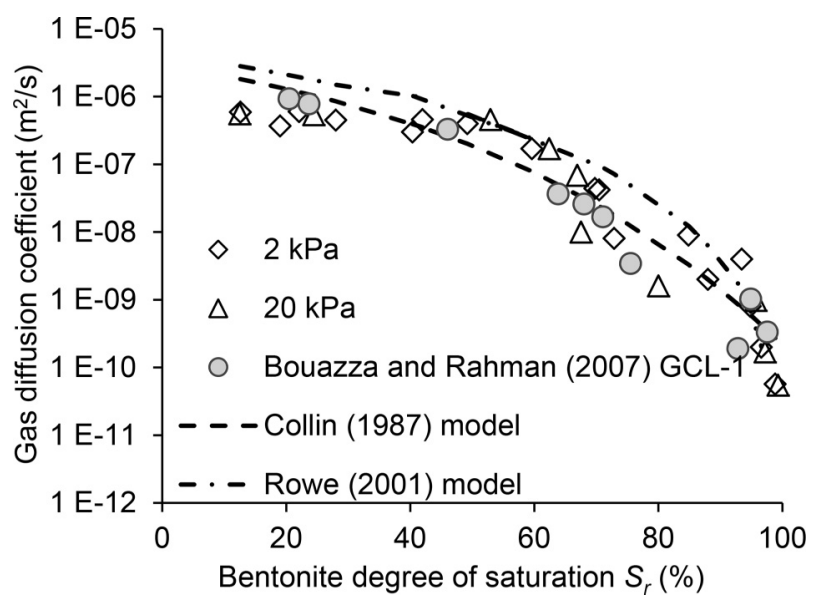

Fig. 10. Variation of gas flow rate against $P_{1}^{2}-P_{2}^{2}$ under 2 and $20 \mathrm{kPa}$ stress conditions.

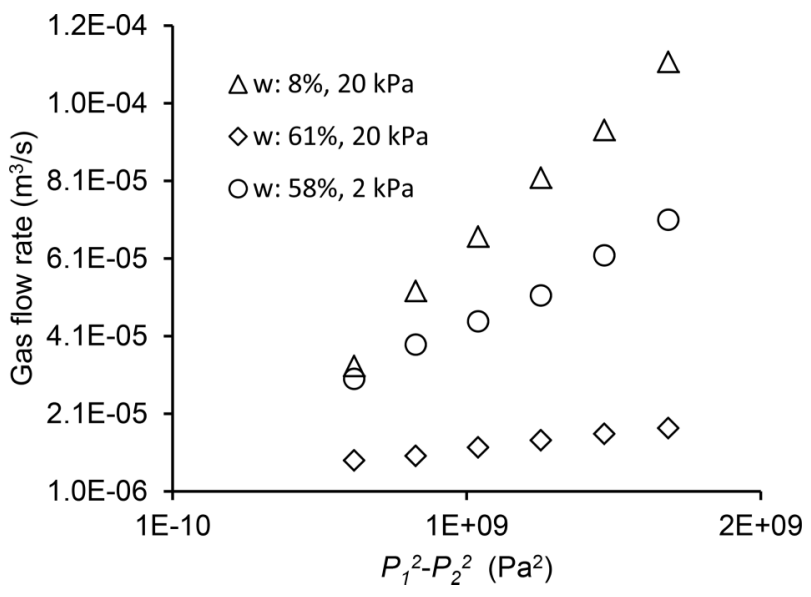

data shown in Fig. 9 compare well with the data reported by Bouazza and Rahman (2007). Additionally, two widely used predictive models - Collin (1987) and Rowe (2001) — for gas diffusion in soils were used in the present investigation (Fig. 9).

The Collin (1987) model accounts for gas diffusion in both the air and liquid phases. The model is expressed by

$$
D_{\mathrm{p}}=\varepsilon D_{\mathrm{a}}\left(\frac{\varepsilon^{2 x+1}}{n_{\mathrm{T}}^{2}}\right)+H \theta D_{\mathrm{w}}\left(\frac{\theta^{2 y+1}}{n_{\mathrm{T}}^{2}}\right)
$$

where $D_{\mathrm{a}}$ and $D_{\mathrm{w}}$ are the diffusion coefficients corresponding to air and water phases, respectively; $\theta$ is the volumetric water content; $H$ is the Henry's law constant, and $n_{\mathrm{T}}$ is the total porosity of the bentonite. The values of $x$ and $y$ are obtained by solving the following two equations (Collin and Rasmuson 1988):

$$
\begin{aligned}
\varepsilon^{2 x}+(1-\varepsilon)^{x} & =1 \\
\theta^{2 y}+(1-\theta)^{y} & =1
\end{aligned}
$$

Typical values of $x$ and $y$ are within the range of $0.6-0.75$ (Aubertin et al. 2000).

Rowe (2001) developed an empirical gas diffusion model for soils with respect to degree of saturation $\left(S_{\mathrm{r}}\right)$ and is expressed as follows: 
Table 2. Estimated Reynolds number.

\begin{tabular}{llllll}
\hline $\begin{array}{l}\text { GCL gravimetric } \\
\text { water content }(\%)\end{array}$ & $\begin{array}{l}\text { Hydration and } \\
\text { test stress }(\mathrm{kPa})\end{array}$ & $\begin{array}{l}\text { Average grain } \\
\text { size }(\mathrm{m})\end{array}$ & $\begin{array}{l}\text { Gas flow } \\
\text { rate }\left(\mathrm{m}^{3} \cdot \mathrm{s}^{-1}\right)\end{array}$ & $\begin{array}{l}\text { Flow velocity } \\
\left(\mathrm{m} \cdot \mathrm{s}^{-1}\right)\end{array}$ & $\begin{array}{l}\text { Estimated Reynolds } \\
\text { number }\end{array}$ \\
\hline 8 & 20 & $5.09 \times 10^{-6}$ & $1.12 \times 10^{-4}$ & $1.43 \times 10^{-2}$ & $4.82 \times 10^{-3}$ \\
58 & 2 & $5.09 \times 10^{-6}$ & $7.10 \times 10^{-5}$ & $9.04 \times 10^{-3}$ & $3.01 \times 10^{-3}$ \\
61 & 20 & $5.09 \times 10^{-6}$ & $1.73 \times 10^{-5}$ & $2.20 \times 10^{-3}$ & $7.32 \times 10^{-4}$ \\
\hline
\end{tabular}

$$
D_{\mathrm{p}}=D_{\mathrm{a}} \exp \left[-A_{\mathrm{R}} \exp \left(B S_{\mathrm{r}}\right)^{c}\right]
$$

where $A_{R}, B$, and $c$ are empirical parameters that can be obtained from the best-fit relationship of gas diffusion coefficient and bentonite degree of saturation.

Both models are plotted in Fig. 9 and were found to correlate well with the experimental data over the range of degree of saturation investigated in the present study. In the case of Collin (1987) model, $x$ and $y$ values were in the range $0.6-0.75$, similar to the range reported by Aubertin et al. (2000) and also Aachib et al. (2004). Rowe (2001) model parameters $A_{R}, B$, and $c$ were 1.85, 0.0165 , and 1.1, respectively, which were similar to Bouazza and Rahman's (2007) reported values $(2.00,0.016$, and 1.1 , respectively) for a similar type of bentonite. Both models can be used to obtain an estimate of the gas diffusion coefficient through bentonite. Furthermore, the predictive models further validate the gas diffusion coefficient measured by the UMS-G.

\section{Gas permeability}

According to Darcy's law shown in eq. (6), flow rate is not proportional to differential pressure $\Delta P$ across the specimen, but rather to the pressure squared $\left(P_{1}^{2}-P_{2}^{2}\right)$ in the context of gas flow through porous media. In Fig. 10, the variation of gas flow rate was plotted with respect to $P_{1}^{2}-P_{2}^{2}$ at different gravimetric water contents and two different stress $(2$ and $20 \mathrm{kPa})$ conditions. The gas flow rate varied linearly with $P_{1}^{2}-P_{2}^{2}$ for water contents and stress conditions showed herein. The estimated Reynolds number (Table 2) for both wet and dry and at different stress conditions ( 2 and $20 \mathrm{kPa}$ ) gave values within the range given by Bear (1972) for laminar flow in porous media. Therefore, it was assumed that Darcy's law is applicable as reported by Bouazza and Vangpaisal (2003) and Rouf et al. (2013). It was also observed from Fig. 10 that the higher gravimetric water content $(61 \%)$ specimen gave about one to two orders of magnitude less gas flow rate compared to the low gravimetric water content $(8 \%)$ specimen at the same applied stress $(20 \mathrm{kPa})$ condition due to the reduction of pore spaces at a high gravimetric water content condition. Additionally, it was also observed that the specimen under $20 \mathrm{kPa}$ gave about one order of magnitude less gas flow rate compared to the specimen under $2 \mathrm{kPa}$ at a similar gravimetric water content $(\sim 60 \%)$ condition. This reduction of flow rate at a higher stress condition might be due to the decrease of pore voids and reduction of pore network by compression caused by the higher stress.

The gas permeability measured by the UMS-G against GCL gravimetric water content under 2 and $20 \mathrm{kPa}$ stress conditions is reported in Figs. $11 a$ and $11 b$, respectively. Additionally, gas permeability measured using the conventional set-up described in Bouazza and Vangpaisal (2003) is included in both figures for comparative purposes.

Figure 11a shows that gas permeability decreased with the increase of gravimetric water content for the $2 \mathrm{kPa}$ stress condition. It can also be observed that UMS-G gas permeability remained constant up to about $60 \%$ gravimetric water content and then decreased by six orders of magnitude due to a gravimetric water content increase of about $85 \%$ (from $60 \%$ to $145 \%$ ). It can also be observed from Fig. 11a that the UMS-G measurements agree well with the data obtained with the conventional measurement device used by Bouazza and Vangpaisal (2003). The gas permeability under the $20 \mathrm{kPa}$ stress condition against gravimetric water content (Fig. 11b) also showed similar decreasing behaviour. Under the $20 \mathrm{kPa}$ stress condition, UMS-G measured gas permeability remained practically the same up to $60 \%$ of gravimetric water content and then reduced from $1.17 \times 10^{-7}$ to $8.00 \times 10^{-13} \mathrm{~m} \cdot \mathrm{s}^{-1}$ when gravimetric water content increased from $60 \%$ to $134 \%$. It can be concluded that the UMS-G measured gas permeability compares well with the conventionally measured gas permeability under the $20 \mathrm{kPa}$ stress condition (Fig. 11b).

The measured gas permeability was plotted against GCL gravimetric water content (Fig. 12a) and GCL apparent degree of saturation (Fig. 12b) for both 2 and $20 \mathrm{kPa}$ stresses. Figure $12 a$ shows that there is no marked difference in the gas permeability under two different ( 2 and $20 \mathrm{kPa}$ ) stress conditions for gravimetric water content $\leq 60 \%$, indicating that the stress effect is negligible, at least in the range of stresses investigated in this study. This is probably due to the insufficient swelling of the bentonite component experienced in this range of gravimetric moisture content. Consequently, this condition resulted in its inability to reduce the pore network at higher $(20 \mathrm{kPa})$ stress compared to the lower $(2 \mathrm{kPa})$ stress investigated in this study. However, at higher gravimetric water content $(>60 \%)$, a noticeable difference in gas permeability values was observed. The gas permeability reduced from $1.17 \times 10^{-7}$ to $8 \times 10^{-13} \mathrm{~m} \cdot \mathrm{s}^{-1}$ when water content increased from $60 \%$ to $145 \%$ at $2 \mathrm{kPa}$ and $60 \%$ to $134 \%$ at $20 \mathrm{kPa}$ stress, respectively, indicating one to three orders of magnitude reduction in gas permeability for specimens hydrated and tested under $20 \mathrm{kPa}$ compared to specimens under $2 \mathrm{kPa}$ (Fig. 12a). This reduction is considered to be due to a much greater reduction of pore space and disruption of the air-filled pore networks at higher stress compared to low stress specimens. These results, for the stress levels considered in this investigation, imply that for this GCL the effect of stress is insignificant up to $60 \%$ gravimetric water content; beyond this range gas permeability was affected by stresses. However, gas permeability in terms of apparent degree of saturation did not show much difference under the two stress conditions (Fig. 12b) considered in this study, similar to the gas diffusion coefficient (Fig. 8).

\section{Conclusion}

A gas flow unified measurement system (UMS-G) was developed to sequentially measure gas diffusion and gas permeability of the same GCL specimen under applied stress conditions. The measurements made with the UMS-G were found to compare very well with measurements made with conventional gas permeability and gas diffusion methods reported from literature on similar GCLs. The UMS-G removes the need to rely on two separate systems and increases further the reliability of the gas properties measurements.

The gas diffusion and gas permeability remained constant up to $40 \%$ and $60 \%$ gravimetric water contents (20\% and $25 \%$ apparent degree of saturation), respectively, under both stress ( 2 and $20 \mathrm{kPa}$ ) conditions. Beyond this range, both the gas diffusion coefficient and gas permeability reduced greatly with the increase of both gravimetric water content and apparent degree of saturation. Additionally, it was found that up to $60 \%$ gravimetric water content, the effect of stress on both gas diffusion and gas permeability was insignificant due to insufficient swelling of bentonite 
Fig. 11. UMS-G and conventionally measured gas permeability with respect to gravimetric water content under (a) $2 \mathrm{kPa}$ stress and (b) $20 \mathrm{kPa}$ stress condition.

(a)

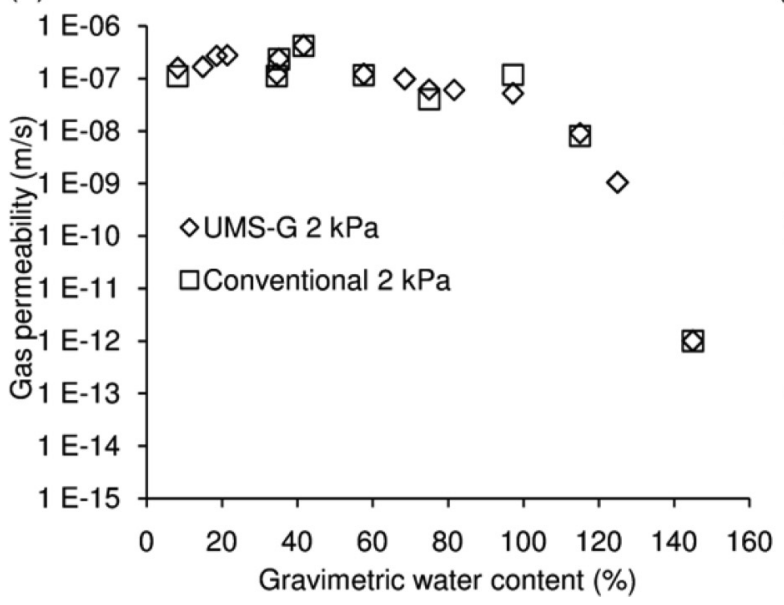

(b)

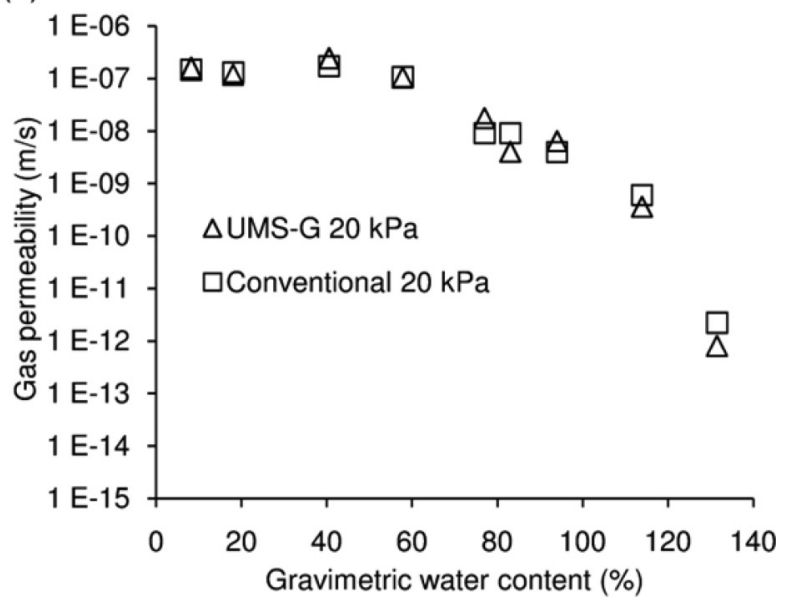

Fig. 12. Gas permeability against (a) gravimetric water content and (b) apparent degree of saturation under 2 and $20 \mathrm{kPa}$ stresses.

(a)

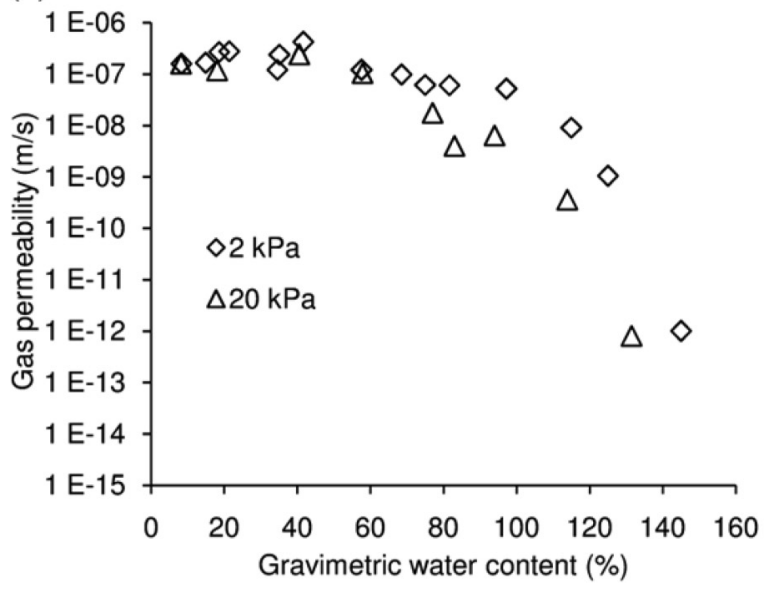

while above this range, both parameters were greatly affected by applied stress considered in this investigation. These findings suggest that at a nominal overburden stress of $20 \mathrm{kPa}$, this GCL needs to be hydrated to $134 \%$ gravimetric water content $(65 \%$ apparent degree of saturation) before gas diffusion and the gas permeability drop to $5.5 \times 10^{-11}$ and $8.0 \times 10^{-13} \mathrm{~m} \cdot \mathrm{s}^{-1}$, respectively, and to an even higher gravimetric water content (apparent degrees of saturation) at lower stress. The results highlight the need for the adjacent layers to have a sufficiently high gravimetric water content to hydrate GCL to at least these levels before coming in contact with gas, either in a landfill or mine tailings application, and that there is enough cover above the GCL to prevent it from subsequently drying to lower than this level of hydration.

\section{Acknowledgements}

This study was supported under the Australian Research Council's Discovery funding scheme (project number DP110104078). The authors' sincere appreciation is extended to the council. The anonymous reviewers made many constructive comments and valuable suggestions. These comments and efforts associated with the review are greatly appreciated by the authors.

\section{References}

Aachib, M., Mbonimpa, M., and Aubertin, M. 2004. Measurement and prediction of the oxygen diffusion coefficient in unsaturated media, with applications

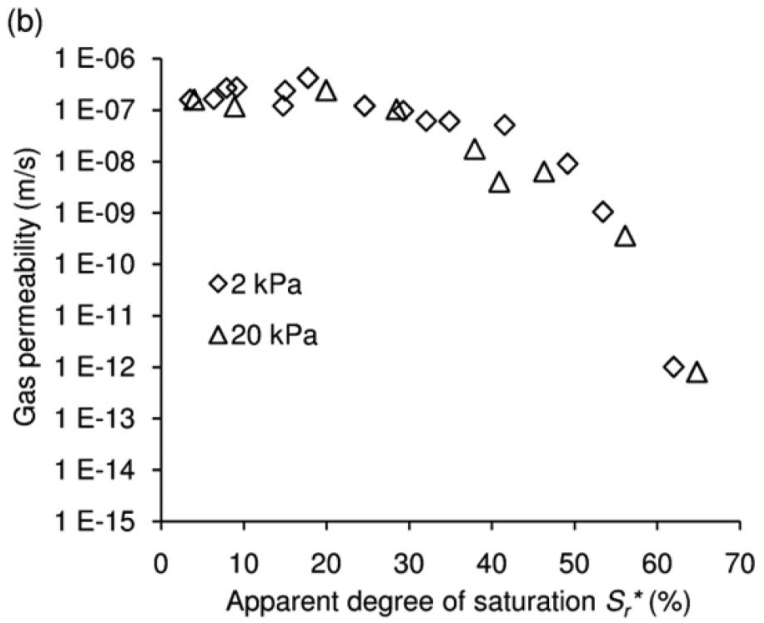

to soil covers. Water, Air, \& Soil Pollution, 156(1):163-193. doi:10.1023/B:WATE. 0000036803.84061.e5.

Abuel-Naga, H.M., and Bouazza, A. 2009. Numerical characterization of advective gas flow through GM/GCL composite liners having a circular defect in the geomembrane. Journal of Geotechnical and Geoenvironmental Engineering, 135(11): 1661-1671. doi:10.1061/(ASCE)GT.1943-5606.0000116.

Abuel-Naga, H.M., and Bouazza, A. 2014. Numerical experiment-artificial intelligence approach to develop empirical equations for predicting leakage rates through GM/GCL composite liners. Geotextiles and Geomembranes, 42(3): 236-245. doi:10.1016/j.geotexmem.2014.04.002.

Ali, M.A., Rao, M.S., Bouazza, A., Rowe, R.K., and Gates, W.P. 2014. Effect of vertical stresses on GCL thermal conductivity. In Proceedings of the 7th International Conference on Environmental Geotechnics, Melbourne, Australia. Edited by Bouazza et al. Engineers Australia. pp. 1201-1208.

Allaire, S.E., Lafond, J.A., Cabral, A.R., and Lange, S.F. 2008. Measurement of gas diffusion through soils: comparison of laboratory methods. Journal of Environmental Monitoring, 10(11): 1326-1336. doi:10.1039/b809461f. PMID: 18974902.

Alzaydi, A.A., Moore, C.A.A., and Rai, I.S. 1978. Combined pressure and diffusional transition region flow of gases in porous media. AICheE Journal, 24(1): 35-43. doi:10.1002/aic.690240105.

Anderson, R., Rayhani, M.T., and Rowe, R.K. 2012. Laboratory investigation of GCL hydration from clayey sand subsoil. Geotextiles and Geomembranes, 31: 31-38. doi:10.1016/j.geotexmem.2011.10.005.

ASTM. 2010. Standard test method for measuring mass per unit area of geotextiles. ASTM standard D5261. ASTM International, West Conshohocken, Pa. doi:10.1520/D5261-10.

ASTM. 2014. Standard test method for measuring mass per unit of geosynthetic clay liners. ASTM standard D5993. ASTM International, West Conshohocken, Pa. doi:10.1520/D5993-14. 
Aubertin, M., Aachib, M., and Authier, K. 2000. Evaluation of diffusive gas flux through covers with a GCL. Geotextiles and Geomembranes, 18(2-4): 215233. doi:10.1016/S0266-1144(99)00028-X.

Bannour, H., Stoltz, G., Delage, P., and Touze-Foltz, N. 2014. Effect of stress on water retention of needlepunched geosynthetic clay liners. Geotextiles and Geomembranes, 42(6): 629-640. doi:10.1016/j.geotexmem.2014.09.001.

Barral, C., Oxarango, L., and Pierson, P. 2010. Characterizing the gas permeability of natural and synthetic materials. Transport in Porous Media, 81(2): 277-293. doi:10.1007/s11242-009-9398-x.

Bear, J. 1972. Dynamics of fluid in porous media. American Elsevier Publishing Company, Inc., Dover, New York.

Bouazza, A. 2002. Geosynthetic clay liners. Geotextiles and Geomembranes, 20(1): 3-17. doi:10.1016/S0266-1144(01)00025-5.

Bouazza, A., and Gates, W.P. 2014. Overview of performance compatibility issues of GCLs with respect to leachates of extreme chemistry. Geosynthetics International, 21(2): 151-167. doi:10.1680/gein.14.00006.

Bouazza, A., and Rahman, F. 2004. Experimental and numerical study of oxygen diffusion through a partially hydrated needle punched geosynthetic clay liner. In Advances in Geosynthetic Clay Liner Technology: 2nd Symposium. ASTM STP 1456. Edited by R.E. Mackey and K. Von Maubeuge. ASTM International, West Conshohocken, Pa. pp. 147-157.

Bouazza, A., and Rahman, F. 2007. Oxygen diffusion through partially hydrated geosynthetic clay liners. Géotechnique, 57(9): 767-772. doi:10.1680/geot.2007. 57.9.767.

Bouazza, A., and Vangpaisal, T. 2003. An apparatus to measure gas permeability of geosynthetic clay liners. Geotextiles and Geomembranes, 21(2): 85-101. doi:10.1016/S0266-1144(02)00058-4.

Bouazza, A., and Vangpaisal, T. 2004. Effect of straining on gas advective flow of a needle-punched GCL. Geosynthetics International, 11(4): 287-295. doi:10. 1680/gein.2004.11.4.287.

Bouazza, A., and Vangpaisal, T. 2007. Gas permeability of GCLs: effect of poor distribution of needle-punched fibres. Geosynthetics International, 14(4): 248-252. doi:10.1680/gein.2007.14.4.248.

Bouazza, A., Vangpaisal, T., and Jefferis, S. 2006. Effect of wet-dry cycles and cation exchange on gas permeability of geosynthetic clay liners. Journal of Geotechnical and Geoenvironmental Engineering, 132(8): 1011-1018. doi:10. 1061/(ASCE)1090-0241(2006)132:8(1011).

Bouazza, A., Vangpaisal, T., Abuel-Naga, H.M., and Kodikara, J. 2008. Analytical modelling of gas leakage rate through a geosynthetic clay linergeomembrane composite liner due to a circular defect in the geomembrane. Geotextiles and Geomembranes, 26(2): 122-129. doi:10.1016/j.geotexmem. 2007.09.001.

Bouazza, A., Zornberg, J., McCartney, J.S., and Singh, R.M. 2013. Unsaturated geotechnics applied to geoenvironmental engineering problems involving geosynthetics. Engineering Geology, 165: 143-153. doi:10.1016/j.enggeo.2012. 11.018.

Bouazza, A., Singh, R.M., Rowe, R.K., and Gassner, F. 2014. Heat and moisture migration in a geomembrane-GCL composite liner subjected to high temperatures and low vertical stresses. Geotextiles and Geomembranes, 42(5): 555563. doi:10.1016/j.geotexmem.2014.08.002.

Bradshaw, S., and Benson, C. 2013. Effect of municipal solid waste leachate on hydraulic conductivity and exchange complex of geosynthetic clay liners. Journal of Geotechnical and Geoenvironmental Engineering, 140(4): 04013038. doi:10.1061/(ASCE)GT.1943-5606.0001050.

Carslaw, H.S., and Jaeger, J.C. 1959. Conduction of heat in solids. 2nd ed. Clarendon Press, Oxford.

Collin, M. 1987. Mathematical modelling of water and oxygen transport in layered soil covers for deposits of pyritic mine tailings. Licentiate treatise, Department of Chemical Engineering, Royal Institute of Technology, Stockholm, Sweden.

Collin, M., and Rasmuson, A. 1988. A comparison of gas diffusivity models for unsaturated porous media. Soil Science Society of America Journal, 52: 15591565. doi:10.2136/sssaj1988.03615995005200060007x.

Currie, J.A. 1960. Gaseous diffusion in porous media. Part 1. A non-steady state method. British Journal of Applied Physics, 11(8): 314-317. doi:10.1088/05083443/11/8/302.

Didier, G., Bouazza, A., and Cazaux, D. 2000. Gas permeability of geosynthetic clay liners. Geotextiles and Geomembranes, 18(2-4): 235-250. doi:10.1016/ S0266-1144(99)00029-1.

Ferry, C., Richon, P., Beneito, A., and Robé, M. 2002. Evaluation of the effect of a cover Layer on radon exhalation from uranium mill tailings: transient radon flux analysis. Journal of Environmental Radioactivity, 63(1): 49-64. doi:10. 1016/S0265-931X(02)00015-2. PMID:12230135.

Gebert, J., Groengroeft, A., and Pfeiffer, E. 2011. Relevance of soil physical properties for the microbial oxidation of methane in landfill covers. Soil Biology \& Biochemistry, 43(9): 1759-1767. doi:10.1016/j.soilbio.2010.07.004.

Hosney, M.S., and Rowe, R.K. 2013. Changes in geosynthetic clay liner (GCL) properties after 2 years in a cover over arsenic-rich tailings. Canadian Geotechnical Journal, 50(3): 326-342. doi:10.1139/cgj-2012-0367.

Hosney, M.S., and Rowe, R.K. 2014. Performance of three GCLs used for covering gold mine tailings for 4 years under field and laboratory exposure conditions. Geosynthetics International, 21(3): 197-212. doi:10.1680/gein.14.00009.

Johnson, D.B., and Hallberg, K.B. 2005. Acid mine drainage remediation options: a review. Science of the Total Environment, 338(1-2): 3-14. doi:10.1016/j. scitotenv.2004.09.002. PMID:15680622.

Kim, H., and Benson, C.H. 2004. Contributions of advective and diffusive oxygen transport through multilayer composite caps over mine waste. Journal of Contaminant Hydrology, 71(1-4): 193-218. doi:10.1016/j.jconhyd.2003.10.001. PMID:15145567.

Lake, C.B., and Rowe, R.K. 2000. Diffusion of sodium and chloride through geosynthetic clay liners. Geotextiles and Geomembranes, 18(2-4): 103-131. doi:10.1016/S0266-1144(99)00023-0.

Liu, Y., Gates, W.P., Bouazza, A., and Rowe, R.K. 2014. Fluid loss as a quick method to evaluate hydraulic conductivity of geosynthetic clay liners under acidic conditions. Canadian Geotechnical Journal, 51(2): 158-163. doi:10.1139/ cgj-2013-0241.

Liu, Y., Bouazza, A., Gates, W.P., and Rowe, R.K. 2015. Hydraulic performance of geosynthetic clay liners to sulfuric acid solutions. Geotextiles and Geomembranes, 43(1): 14-23. doi:10.1016/j.geotexmem.2014.11.004.

Lundgren, T. 2001. The dynamics of oxygen transport into soil covered mining waste deposits in Sweden. Journal of Geochemical Exploration, 74(1-3): 163173. doi:10.1016/S0375-6742(01)00182-0.

Makusa, G.P., Bradshaw, S.L., Berns, E., Benson, C.H., and Knutsson, S. 2014. Freeze-thaw cycling concurrent with cation exchange and the hydraulic conductivity of geosynthetic clay liners. Canadian Geotechnical Journal, 51(6): 591-598. doi:10.1139/cgj-2013-0127.

Massmann, J.W. 1989. Applying groundwater flow models in vapor extraction system design. Journal of Environmental Engineering, 115(1): 129-149. doi:10. 1061/(ASCE)0733-9372(1989)115:1(129).

McBean, E.E., Rovers, F.A., and Farquhar, G.J. 1995. Solid waste landfill: Engineering and design. Prentice-Hall PTR, Englewood Cliffs, N.J.

Meer, S., and Benson, C. 2007. Hydraulic conductivity of geosynthetic clay liners exhumed from landfill final covers. Journal of Geotechnical and Geoenvironmental Engineering, 133(5): 550-563. doi:10.1061/(ASCE)1090-0241(2007)133: $5(550)$.

Mendes, M.J.A., Pierson, P., Touze-Foltz, N., Mora, H., and Palmeira, E.M. 2010. Characterisation of permeability to gas of geosynthetic clay liners in unsaturated conditions. Geosynthetics International, 17(5): 344-354. doi:10.1680/ gein.2010.17.5.344.

Millington, R.J., and Quirk, J.P. 1961. Permeability of porous solids. Transactions of the Faraday Society, 57: 1200-1207. doi:10.1039/tf9615701200.

Mudd, G.M. 2008. Radon releases from Australian uranium mining and milling projects: assessing the UNSCEAR approach. Journal of Environmental Radioactivity, 99(2): 288-315. doi:10.1016/j.jenvrad.2007.08.001. PMID:17913316.

Norrish, K. 1954. The swelling of montmorillonite. Transactions Faraday Society, 18: $120-134$. doi:10.1039/df9541800120.

Petrov, R.J., and Rowe, R.K. 1997. Geosynthetic clay liner (GCL) - chemical compatibility by hydraulic conductivity testing and factors impacting its performance. Canadian Geotechnical Journal, 34(6): 863-885. doi:10.1139/t97-055.

Pitanga, H.N., Pierson, P., and Vilar, O.M. 2011. Measurement of gas permeability in geosynthetic clay liners in transient flow mode. Geotechnical Testing Journal, 34(1): 27-33. doi:10.1520/GTJ103000.

Rayhani, M.T., Rowe, R.K., Brachman, R.W.I., Take, W.A., and Siemens, G. 2011 Factors affecting GCL hydration under isothermal conditions. Geotextiles and Geomembranes, 29: 525-533. doi:10.1016/j.geotexmem.2011.06.001.

Renken, K., Yanful, E.K., and Mchaina, D.M. 2005. Effective oxygen diffusion coefficient and field oxygen concentrations below a geosynthetic clay liner covering mine tailings. In Waste containment and remediation. Geotechnical Special Publication 142. ASCE. pp. 1-15. doi:10.1061/40789(168)24.

Rolston, D.E., and Moldrup, P. 2002. Gas diffusivity: methods of soil analysis. In Methods of soil analysis, Part 4: Physical methods. Edited by J.H. Dane and C. Topp. Soil Science Society of America, Madison, Wisc. pp. 1113-1139.

Rouf, M.A., Hamamoto, S., Kawamoto, K., Sakaki, T., Komatsu, T., and Moldrup, P. 2012. Unified measurement system with suction control for measuring hysteresis in soil-gas transport parameters. Water Resources Research, 48(2): W02506. doi:10.1029/2011WR010615.

Rouf, M.A., Singh, R.M., Bouazza, A., and Rowe, R.K. 2013. Geosynthetic clay liner gas permeability relationship with moisture content and suction under pre-conditioning stresses. In Proceedings of the International Symposium on Coupled Phenomena in Environmental Geotechnics, Torino, Italy. Edited by Manassero et al. CRC Press/Balkema. pp. 435-441. doi:10.1201/ b15004-56.

Rouf, M.A., Singh, R.M., Bouazza, A., Rowe, R.K., and Gates, W.P. 2015a. Gas permeability of partially hydrated geosynthetic clay liner under two stress conditions. Environmental Geotechnics. [Published online ahead of print 11 September 2015.] doi:10.1680/envgeo.14.00009.

Rouf, M.A., Bouazza, A., Rao, M.S., Gates, W.P., and Rowe, R.K. 2015b. Water vapour adsorption and desorption in GCLs. Geosynthetics International. [Published online ahead of print 5 October 2015.] doi:10.1680/jgein.15.00034.

Rowe, R.K. 1998. Geosynthetics and the minimization of contaminant migration through barrier systems beneath solid waste. In Proceedings of the 6th International Conference on Geosynthetics, Atlanta, March 1988. Vol. 1, pp. 27-103.

Rowe, R.K. (Editor). 2001. Barrier systems. In Geotechnical and geoenvironmental engineering handbook. Kluwer Academic, Norwell, Mass. pp. 739-788.

Rowe, R.K., and Hosney, M.S. 2013. Laboratory investigation of GCL performance 
for covering arsenic contaminated mine wastes. Geotextiles and Geomembranes, 39: 63-77. doi:10.1016/j.geotexmem.2013.06.003.

Rowe, R.K., Ashe, L.E., Take, W.A., and Brachman, R.W.I. 2014. Factors affecting the down-slope erosion of bentonite in a GCL. Geotextiles and Geomembranes, 42(5): 445-456. doi:10.1016/j.geotexmem.2014.07.002.

Scalia, J., IV, and Benson, C. 2011. Hydraulic conductivity of geosynthetic clay liners exhumed from landfill final covers with composite barriers. Journal of Geotechnical and Geoenvironmental Engineering, 137(1): 1-13. doi:10.1061/ (ASCE)GT.1943-5606.0000407.

Shackelford, C.D. 2014. The ISSMGE Kerry Rowe Lecture: The role of diffusion in environmental geotechnics. Canadian Geotechnical Journal, 51(11): 12191242. doi:10.1139/cgj-2013-0277.

Shackelford, C.D., Benson, C.H., Katsumi, T., Edil, T.B., and Lin, L. 2000. Evaluating the hydraulic conductivity of GCLs permeated with non-standard liquids. Geotextiles and Geomembranes, 18(2-4): 133-161. doi:10.1016/S02661144(99)00024-2.

Singh, R.M., and Bouazza, A. 2013. Thermal conductivity of geosynthetics. Geotextiles and Geomembranes, 39: 1-8. doi:10.1016/j.geotexmem.2013.06.002.

Thomas, E.M., Shannon, L.B.-H., Mira, S.O, and Fred, D.T. 2010. Mass transfer within surface soils. In Handbook of chemical mass transport in environment. Edited by L.J. Thibodeaux and D. Mackay. CRC Press. pp. 159-212.

Troeh, F.R., Jabro, J.D., and Kirkham, D. 1982. Gaseous diffusion equations for porous materials. Geoderma, 27(3): 239-253. doi:10.1016/0016-7061(82) 90033-7.

Vangpaisal, T. 2002. Gas permeability of geosynthetic clay liners under various conditions. Ph.D. thesis, Monash University, Melbourne, Australia.

Vangpaisal, T., and Bouazza, A. 2004. Gas permeability of partially hydrated geosynthetic clay liners. Journal of Geotechnical and Geoenvironmental Engineering, 130(1): 93-102. doi:10.1061/(ASCE)1090-0241(2004)130:1(93).

Yao, Y., Su, Y., Wu, Y., Liu, W., and He, R. 2015. An analytical model for estimating the reduction of methane emission through landfill cover soils by methane oxidation. Journal of Hazardous Materials, 283(11): 871-879. doi:10.1016/j. jhazmat.2014.10.035. PMID:25464331.

\section{List of symbols}

A cross-sectional area of the porous material $\left(\mathrm{m}^{2}\right)$

$A_{\mathrm{R}}, B, c$ empirical parameters in eq. (13)

$C(L, t)$ gas concentration in the diffusion chamber at time $t>0$ $\left(\mathrm{g} \cdot \mathrm{m}^{-3}\right)$, at $z>\mathrm{L}$

$C_{0}$ gas concentration in the atmosphere (source) $\left(\mathrm{g} \cdot \mathrm{m}^{-3}\right)$, at $z<0$

$C_{\mathrm{g}}$ concentration difference in the gaseous phase $\left(\mathrm{g} \cdot \mathrm{m}^{-3}\right)$

$C_{\mathrm{i}}$ gas concentration in the diffusion chamber at $t=0\left(\mathrm{~g} \cdot \mathrm{m}^{-3}\right)$, at $z>L$

$C_{\mathrm{r}}$ relative gas concentration in diffusion chamber $\left(\mathrm{g} \cdot \mathrm{m}^{-3}\right)$

$\partial C_{\mathrm{g}} / \partial z$ gas concentration gradient $\left(\mathrm{g} \cdot \mathrm{m}^{-4}\right)$

$D_{\mathrm{a}}$ gas diffusion coefficient in free air $\left(\mathrm{m}^{2} \cdot \mathrm{s}^{-1}\right)$

$D_{\mathrm{p}}$ gas diffusion coefficient $\left(\mathrm{m}^{2} \cdot \mathrm{s}^{-1}\right)$
$D_{\mathrm{w}}$ gas diffusion coefficient in water phase $\left(\mathrm{m}^{2} \cdot \mathrm{s}^{-1}\right)$

$g$ gravitational acceleration $\left(\mathrm{m} \cdot \mathrm{s}^{-2}\right)$

$H$ Henry's law constant

$H_{\mathrm{GCL}}$ thickness of GCL (m)

$H_{\mathrm{LG}}$ thickness of lower geotextiles (m)

$H_{\mathrm{UG}}$ thickness of upper geotextiles (m)

$h$ ratio of air content in GCL specimen to length of free space below GCL specimen including diffusion chamber length $\left(\mathrm{m}^{-1}\right)$

$J$ mass diffusive flux of the gas $\left(\mathrm{g} \cdot \mathrm{m}^{-2} \cdot \mathrm{s}^{-1}\right)$

$\mathrm{K}$ gas permeability $\left(\mathrm{m} \cdot \mathrm{s}^{-1}\right)$

$k$ intrinsic permeability of the porous material $\left(\mathrm{m}^{2}\right)$

$L$ length (height or thickness) of specimen (m)

$L_{\mathrm{a}}$ height of the diffusion chamber + length of the free space below the GCL specimen (m)

$M_{\text {bent }}$ mass per unit area of bentonite $\left(\mathrm{kg} \cdot \mathrm{m}^{-2}\right)$

$M_{\mathrm{GCL}}$ mass per unit area of GCL $\left(\mathrm{kg} \cdot \mathrm{m}^{-2}\right)$

$M_{\mathrm{GT}}$ mass per unit area of geotextile $\left(\mathrm{kg} \cdot \mathrm{m}^{-2}\right)$

$M_{\mathrm{LG}}$ mass per unit area of lower geotextiles $\left(\mathrm{kg} \cdot \mathrm{m}^{-2}\right)$

$M_{\text {UG }}$ mass per unit area of upper geotextiles $\left(\mathrm{kg} \cdot \mathrm{m}^{-2}\right)$

$n_{\mathrm{T}}$ total porosity of the bentonite

$P$ pressure $\left(\mathrm{N} \cdot \mathrm{m}^{-2}\right)$

$P_{1}$ inlet pressure $\left(\mathrm{N} \cdot \mathrm{m}^{-2}\right)$

$\mathrm{P}_{2}$ outlet pressure which is atmospheric pressure $\left(\mathrm{N} \cdot \mathrm{m}^{-2}\right)$

$d \mathrm{P} / \mathrm{dz}$ pressure gradient $\left(\mathrm{N} \cdot \mathrm{m}^{-1}\right)$

$Q$ one-dimensional volumetric flow rate of gas in porous media $\left(\mathrm{m}^{3} \cdot \mathrm{s}^{-1}\right)$

$\mathrm{Q}_{2}$ one-dimensional volumetric flow rate of gas entering the atmosphere $\left(\mathrm{m}^{3} \cdot \mathrm{s}^{-1}\right)$

$R_{e}$ Reynolds number

$S_{\mathrm{r}}$ bentonite degree of saturation

$S_{\mathrm{r}}^{*}$ apparent degree of saturation (\%)

$t$ time (s)

$w$ gravimetric moisture content of GCL (\%)

$w_{\text {ref }}$ maximum gravimetric moisture content that GCL can reach during hydration (\%)

$z$ thickness, height, etc. (m)

$\alpha$ positive root

$\alpha_{1}$ first positive root of $h L=\alpha_{n} L_{n} \tan \left(\alpha_{n} L_{n}\right)(n=1,2 \ldots)$

$\varepsilon$ air-filled porosity $\left(\mathrm{m}^{3} \cdot \mathrm{m}^{-3}\right)$

$\theta$ volumetric water content of bentonite $\left(\mathrm{m}^{3} \cdot \mathrm{m}^{-3}\right)$

$\mu$ dynamic viscosity of gas $\left(\mathrm{N} \cdot \mathrm{s} \cdot \mathrm{m}^{-2}\right)$

$\rho$ density of the $N_{2}$ gas $\left(\mathrm{kg} \cdot \mathrm{m}^{-3}\right)$ 